\title{
Recurrent pregnancy loss: An outcome of cytokine breach at materno-embryonic interface
}

\author{
Shafat $\mathrm{Ali}^{1}$, Sabhiya Majid ${ }^{2}$, Md. AlI ${ }^{1}$, Shahnaz Taing ${ }^{2}$, and Muneeb Rehman ${ }^{3}$ \\ ${ }^{1}$ University of Kashmir \\ ${ }^{2}$ Government Medical College Srinagar \\ ${ }^{3}$ King Saud University
}

July 16, 2020

\begin{abstract}
Abstract: Recurrent pregnancy loss (RPL) is a prominent reproductive disease that distresses about $2 \%-5 \%$ of couples. RPL is the loss of two or more successive spontaneous pregnancies prior to 20th week of the embryo development. The commencement of pregnancy necessitates implantation of the embryo into responsive maternal decidua synchronized with the process of placentation, decidual and myometrial trophoblast incursion as well as refashioning of spiral blood arteries of uterus. The collapse of any of the processes fundamental for accomplishment of pregnancy may result into an array of pregnancy problems including spontaneous pregnancy loss. Human female with normally working immune system may well carry a partly-allogenic embryo to full tenure with no apparent rejection via adjustment of the immune system so as to accept and tolerate the embryo. The endometrium of human female manufactures an extensive range of cytokines during the proliferative and secretory stage of menstrual cycle. These endometrial cytokines are thought as major players for making the uterus ready for embryo implantation and placental development. Decidual cytokines regulate the invasion of trophoblast and remodeling of spiral arteries as well as take part in immune suppression to accomplish the pregnancy. Deterrence of fetal dismissal by the mother needs a regulated milieu, which takes place essentially at the embryo-maternal interface and the tissues of uterus. The reasons of RPL remain anonymous in a large number of cases that leads to difficulties in management and severe trauma in couples. Further study of novel factors is wanted to establish treatment protocols for RPL.
\end{abstract}

\section{Introduction}

The premature pregnancy failure is acknowledged to affect approximately $15 \%$ of all the pregnancies recognized clinically. Recurrent pregnancy loss (RPL) is defined as [?]2 successive pregnancy failures affecting less than $5 \%$ of human female that belong to the reproductive age category [1,2]. Even though the precise cause of nearly $50 \%$ of recurrent pregnancy losses remains unclear, nevertheless maternal immunological dismissal may perhaps justify the majority of these unexplained cases of pregnancy loss $[2,3]$. Healthy human females having normal functioning immune system may complete a half-allogenic conceptus to full tenure without clear refusal by modifying the immune system so as to accept and tolerate the embryo [4]. Acceptance and tolerance of a half-allogenic conceptus recommends the role of whole body regulatory processes in normal pregnant women $[5,6]$. The exact devices that shield the embryo from the maternal immune assault and dismissal are poorly implicit. However, the genetically incompatible embryo escapes maternal immune rejection perhaps as a result of communication among several vital cytokines exuded by maternal and embryonic cells at embryo-maternal interface [2, 7]. Human female endometrium develops into decidua receptive for implantation [7] via the hormone and growth factor driven process known as decidualization wherein endometrial stromal cells are differentiated into decidual cells that support growing embryo [8]. The decidual cells facilitate the early development of blastocyst [8], shields the embryo from maternal immune cell attack [9], gives dietetic support to the budding embryo before the formation of the placenta [8,9] and 
assist in parturition[8]. Endometrial decidualization is essential for the establishment of pregnancy [10]. The process of decidualization involves the endometrial stromal cell reprogramming which includes the production of diverse mediators such as cytokines and chemokines, and selective recruitment of immune cells. This physiologic process involves alteration in endometrial stromal cell secretome that leads to the formation of immunomodulatory factors [11]. The trophoblastic cell stimulation is also vital for the differentiation of endometrial tissue [7].

The endometrium of human female synthesizes a broad array of cytokines during the follicular phase and luteal phase of menstrual cycle $[12,13]$. These cytokines are assumed crucial for modulating the uterine atmosphere and making the uterus ready for implantation of the growing conceptus as well as formation of working placenta during pregnancy. The embryo-maternal interface and uterine tissues primarily provide a regulated atmosphere required for avoiding the maternal dismissal of the embryo. Typically, the naïve CD4+ $\mathrm{T}$ cells are the main cytokine manufacturers and can be classified into various subsets such as Th1, Th2, Th17 and T regulatory cells. The cytokines produced by $\mathrm{T}$ helper cells are additionally manufactured in excess by various cell types including trophoblast cells, stromal cells, epithelial cells, maternal T lymphocytes, macrophages, natural killer (NK) cells and other maternal leucocytes at the maternal-embryonic interface $[12,14]$ which indicates that the development and continuation of the embryonic-placental module depends on these cytokines (Table $1 \& 2$ ). The cytokines that are present at the interface of maternal-embryonic unit could have an effect on uterus milieu via the regulation of embryo implantation, growth of placenta, cytotrophoblast production, blood vessel formation, extra-villous trophoblast cell invasion, refashioning of spiral arteries, cell development and apoptosis as well as induction of embryonic tolerance [12,64-68]. The success of pregnancy essentially depends on reciprocal signaling between the mother and developing blastocyst and decidual receptiveness all through the implantation window $[12,69]$.

Cytokines along with cell surface receptors are believed to act as communication mediators between trophoblastic and decidual cells [70]. The communication among the cells at maternal-embryonic interface modifies the expression of the variety and amount of cytokines. The immune tolerance or immune stimulation may be linked to the variations in the pattern of $\mathrm{T}$ cell cytokines [7]. Earlier the CD4 $+\mathrm{T}$ cells of human beings were categorized into Th1 and Th2 cell types depending upon their pattern of cytokine production [71]. Later a new subpopulation of CD4+ T cells termed as Th17 cells was reported that manufacture IL17 [7]. The Th1 type of cells participate in cellular immunity via producing IL2 and IFN $\gamma$ whereas Th2 type of cells discharge IL4, IL5 and IL13 and participate in humoral immunity [22]. Th1 cytokines have been attributed the fatal role as they are believed fundamental in the rejection of acute allograft via Th1 dependent effector mechanisms [72, 73]. Conversely, Th2 category of cytokines appears essential for inducing and upholding the allograft tolerance [7, 74-76]. Th1 cytokines as well have been reported necessary for the continuance of pregnancy e.g. IFN $\gamma$ is known as a key cytokine involved in remodeling of spiral blood arteries and productive outcome of pregnancy [12, 77-79]. Moreover, a study on various Th2 type of knockout mouse like IL4, IL5, IL6 and IL13 has shown normal product of reproduction $[12,80,81]$ even if dissimilar systems may be associated with upholding of the pregnancies in mouse and human suggesting the insignificance of predominant Th2 immunity in accomplishment of the pregnancy. In case of abortion, supremacy of Th1 immunity has been reported, however, dominance of Th2 immunity is too observed in RPL [25, 81-85]. Consequently, an ample equilibrium for Th1/Th2 immunity with a little inclination toward Th2 kind of immunity maybe appropriate in maintaining the pregnancy. Hyper stimulation of either type of immunity i.e., Th1 or Th2 is thought to be destructive for normal pregnancy [81]. In addition to Th1 and Th2 type of cytokines, IL15 and IL18 have been observed at the maternal-embryonic interface $[64,86]$. The expansion of the T helper subpopulation to incorporate Th17 and Treg cells, in fact, defied the Th1/Th2 paradigm and added to its complexity [12]. Th17 cells that produce a potent pro-inflammatory IL17 cytokine are essential players in the induction of inflammation and rejection. The IL17 cells are reported to interact with Th1 type of cells and associated with pathogenicity of allergy, autoimmune disorders, transplant dismissal, pregnancy disorders and RPL [87-92]. Treg cells are recognized as participants in mediating the maternal tolerance towards the embryo [93-95].

The materno-embryonic tolerance prevents the rejection of embryonic tissues and causes successful estab- 
lishment of pregnancy [96-101]. The proliferation in Treg cells is with associated normal pregnancy, whereas the diminished number of Treg cells brings about the failure of pregnancy due to immune rejection of the embryo [95, 102]. Recent research reports have shown elevated number of Th17 type of cells in the decidua and peripheral blood of the patients that have a history of spontaneous idiopathic RPL [81, 102, 103]. The decidual tissue in RPL women has shown over-expression of ROR $\gamma$ (master transcription factor) for Th17 cells and increased concentration of IL23, that participates as a vital factor in the expansion of Th17 cells $[81,102]$. In recent times, the occurrence of stromal cell derived IL17 has been reported in the first trimester of human pregnancy that performs a constructive function in supporting the pregnancy via the recruitment of Th17 cells and promotion of trophoblast invasion, in addition to, the inhibition of trophoblast apoptosis [104]. On the other hand, the Th17 cells have been discovered to be infrequent and outnumbered by the intensification of Treg cells [12]. The number of Treg cells and associated functions significantly decrease both in decidual tissue and peripheral blood of RPL women either pregnant or non-pregnant suggesting the important role of Treg cells in RPL pathogenesis [94]. The balance between Treg and Th17 cells as well as the Th17/Treg ratio has been reported shifting towards Th17 cells during pregnancy-related disorders that produce an inflammatory micro milieu at the materno-embryonic interface [91,105]. A most recent study also reported that the frequency of Treg cell decreases while as that of Th17 cells increases in RPL patients [106]. This suggests that pregnancy success needs a tightly regulated Th1, Th2, Th17, and Treg balance and any deviation may collapse the pregnancy (Table 3). The change in the decidual cytokine expression has been made known to be allied with spontaneous pregnancy loss [12]. Therefore, aberrant production of certain cytokines might be a potential factor leading to RPL. However, the exact mechanistic mode employed by aberrant immunological factors for causing RPL is undecided, but may involve modulation or imbalance between different immune cells specifically the $\mathrm{T}$ cell subsets.

\section{Decidualization: A preparation for pregnancy}

Pregnancy triggers an intricate array of active changes that allows close approximation of genetically dissonant embryonic and maternal tissues [116]. The accomplishment of human pregnancy robustly relies on the quality of the embryo in addition to the physiological condition of the uterine lining termed endometrium. The endometrium undergoes decidualization so that the uterus is prepared for the embryo implantation and pregnancy. During the process of decidualization the endometrial epithelium, blood vessels along with stroma are changed into a special tissue termed decidua (Fig 1) [117-119]. The process of decidualization begins in the midsecretory period of menstrual cycle independently of blastocyst implant due to the raised concentration of ovarian hormones such as estrogen and progesterone [119-122]. During the reproductive cycle in normal women CD4+ T cells are significantly altered (Table 4) and show a considerable difference in their densities between early luteal and mid-luteal phase. They exhibit lower levels during mid-luteal and late luteal phases as compared to early follicular phase [33]. Decidualization process plays a key part in the regulation of invasion of trophoblasts, protection against oxidative stress and modulation of specialized uNK cells (CD56 bright and CD16 dim) [118] uNK cellular entities on the other hand regulate angiogenesis, remodeling of vessels and inflammation through IL11 and 1L15 [130-133].

During the process of decidualization, stromal cells of human endometrium are modified into decidual cells [134-137] via severe inflammatory responses with subsequent anti-inflammatory condition as a result of retinoid and corticosteroid signaling pathway reprogramming. The inflammatory responses orchestrate the implantation window [134]. The decidualization of endometrial stromal cells is essential for the implantation of embryo [138]. The implantation of embryo is important for normal pregnancy [136]. Decidualization has been recognized as a vital event for facilitating embryo implantation and successful pregnancy establishment [135-137]. Decidualization depends on progesterone which acts via nuclear-progesterone-receptor (PR) [137]. A wider range of factors (Table 5) contribute for the successful decidualization. Any impairment in the decidualization process causes failure of implantation, pregnancy loss and other pregnancy related abnormalities in later trimesters [138]. Recently, basal decidua of RPL patients has been found containing more vasculature (veins, lymph vessels, and arteries) compared to fertile women [154]. Conversely, the secretory endometrium of non-pregnant RPL patients has reported highly dense blood vasculature [131]. Various pathological conditions that reduce reproductive potential, such as polycystic ovarian syndrome, endometrio- 
sis, antiphospholipid syndrome, and RPL have been found showing error in the timing and state of decidual cell differentiation [155]. During pregnancy the decidualization brings about slow but sure and intense change in gene expression, cellular physiology as well as modification of tissue until the total development of the placental tissue. The examination of decidual secretome and study of expression of genes reveal the details of the changes that occur in the signaling messengers or intermediate molecules, factors of transcription, chemokines molecules, factors of growth/hormones, cyto-skeletal organization, cytokine molecules, contents of extracellular matrix, molecules of adhesion, receptors/ligands, water and ion transportation, mechanism of cell cycle regulation, trafficking within the cell, migratory process and actions, formation of blood vessels, decidual receptiveness and the process of implantation [119, 156-160].

The decidua is an ephemeral, however, a vital uterine podium that develops from the differentiation of stromal cells of endometrium, freshly formed motherly blood and vascular cells in the interior and exterior of the vessels. Decidual development is a strong tissue remodeling wherein the residential and employed cells of immune system undergo humoral as well as physical modifications subsequent to blastocyst attachment on the uterine wall [9]. During the course of decidualization mushroom like endometrial projections termed pinopods connect with the blastocyst via tight junctions for the communication and employment of cells of immune system. The cells of maternal immune system may communicate with the cells of embryo right through the syncytiotrophoblast which covers up the placental villi and the implantation site where the deciduas is invaded by extra villous trophoblasts [161]. The decidua has been recognized as a vital maternal uterine tissue that guards the embryo from maternal immune cell attack as well as gives dietetic support for the budding embryo preceding to the formation of the placenta [9]. Adaptive immunity is believed to be modulated by decidual macrophages and uterine dendritic cells (DCs) by means of cytokine balancing and promoting the production of Treg cells. The remodeling of uterine tissue and blood vessels during the process of decidualization provides physical and nutritional support to the growing embryo [9]. The various signaling networks are triggered between the mother and the embryo at the time of implantation due to the release of an array of cytokine and chemokine molecules from the cells of embryo as well as the cells of decidua [9], which are extremely large polygonal cells with pale-staining nuclei and eosinophilic granular cytoplasm (Fig 2) [162]. A huge figure of maternal decidual immune cells is believed to establish equilibrium between antipathogenic resistance and tolerance of embryo. The key cellular population includes the cells of innate immunity, for instance, uNK cells and macrophages [9]. The decidual cells subsequent to the initiation of their proliferation and differentiation go on to the process of multinuclearization, i.e. duplication of DNA molecule without cell cleavage (endo-reduplication) that permits multiple gene expression and the discharge of synthesized proteins with the expenditure of smaller amount of energy and this course of action is deemed as an essential hallmark for the maturation of decidua in human beings and rodents $[9,163,164]$.

IL11 is a vital cytokine associate with decidualization $[119,165]$ implantation $[119,166]$ as well as placentation $[119,167]$. It is activated either alternatively or by the convergence of signaling pathways of prokineticin-1 $[119,168]$ activin A $[119,169]$ relaxin and PGE2 (Postaglandin E2) $[119,170]$ which are recognized as early inducers of decidualization. IL11 is stimulated by relaxin and PGE2 via cAMP/PKA signaling pathway [119, 170] whereas prokineticin-1 triggers it via calcineurin-NFAT signaling pathway [119, 168]. Any perturbation in the decidualization process causes the breakdown of materno-embryonic interface and pregnancy loss [171].

Studies on knockout mouse for IL11R $\alpha$ have shown that lack of IL11 signaling (mediated via IL11R $\alpha$-/) is responsible for impaired decidualization and decreased proliferation of uterine stromal cells [9, 172, 173] as well as causes disrupted expression of protease inhibitors [174, 175] and also interrupts invasion of trophoblasts leading to its anarchic proliferation and finally pregnancy loss [176] and resorption of embryo [177]. IL11 signaling is vital for enough decidualization in mouse and promoting decidualization in human [178]. The expression of IL11 has been reported crucial for decidualization of human stromal cells and the irregularity in its production in endometrium might be related with several infertility types [177]. The vital role played by IL11 in in-vitro stromal cell decidualization in human endometrium supports the fact that IL11 serves as a key factor for correct process of decidualization in human beings like in mice [177]. The endometrial stromal cells obtained from women affected by primary infertility show defective decidualization in comparison to cells isolated from normal women, depicting compromised IL11 production in former women 
[177]. The aberrant IL11 and IL11R $\alpha$ production in decidual and placental tissue of women with an-embryonic pregnancies emphasizes the potential significance of IL11 signaling in early placentation [179]. Nevertheless, similar IL11R $\alpha$ expression has been observed in the decidualized stromal cells of fertile and infertile women, supporting the significance of expressional modulation of IL11 and not that of IL11R $\alpha$ in regulating human endometrial decidualization [177]. In addition, IL11 signaling plays a crucial and complex role in endometrial preparation for embryo implantation, invasion of early trophoblasts and decidualization of stromal cells in primates and abnormal IL11signaling or action blockade may result in diminished fertility [178]. The signaling defects of IL11 in endometrium may well be utilized as one of potential targets for developing therapeutic approaches in upcoming years for infertility treatment [177]. The course of preparation for implantation and pregnancy and the possible pregnancy outcome depending on predominant cytokine milieu in uterus is briefly depicted in Fig $\mathbf{3}$. The imperfect development of decidua during early pregnancy may well result in infertility or afterward produce complications such as pre-term birth, preeclampsia and RPL [9, 99, 180, 181]. However, the pregnancy outcome both in spontaneous conception or conception subsequent to in-vitro fertilization may be improved via approaches developed after understanding different molecular signaling networks responsible for coordinating strategies for successful implantation and decidualization [180]. IL15

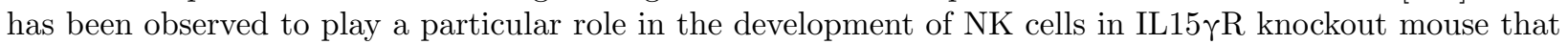
lacks NK cells [182]. IL15 is considered as a key factor for stimulating in-vivo proliferation of uNK cells [183] given that IL15 exists in glands as well as stroma [184].

\section{Cytokine imbalance at materno-embryonic interface and RPL}

The endometrium originates during early stages of development from uro-genital ridge and develops in uterus [185]. It is composed of two main layers- the basal and functional layers. The basal layer is located adjacent to myometrial layer and regenerates the functional layer which is shed during menstruation. On the other hand the functional layer that forms two-third of the thickness of endometrium performs the role of secretion, proliferation and degeneration of tissue [186]. The endometrium contains stromal and epithelial cells supplied with a specific vasculature and this uterine lining attains maturity at the age of puberty as well as orchestrates menstrual cycle despite the fact that it provides an immuno-protected location for embryonic allograft implantation. However, the tissues including prostate and breasts that are proliferative and responsive to hormones make the endometrial tissue pathology-prone [185]. The environment of endometrium has a very important role in the embryo implantation and the placental development during early pregnancy. In case of normal pregnancy, the partly-allogenic embryo survives due to the stimulation of maternal immune tolerance via Treg cells along with anti-inflammatory Th2 profile [51]. A number of studies reported the imbalance of immune cells (Table 6) and cytokine expression (Table 7 \& 8) among human females that suffer from RPL and implantation failure [187]. Imbalance in immunological reactions and deregulation in the activity of subsets of T cells may produce reproductive failure such as miscarriage [106]. Higher Th17 cell percentage and lower Treg cell number has been reported in the decidua of women with idiopathic RPL compared to that of normal controls suggesting the association of alterations in Th17 and Treg cell ratio at materno-embryonic interface with the pathogenesis of idiopathic RPL [220]. The type 1 cytokines including IFN $\gamma$, IL17, IL1 $\beta$ and $\mathrm{TNF} \alpha$ exert proinflammatory effects while the type 2 cytokine that produce anti-inflammatory effects include IL4, IL10 and IL1ra [221]. The equilibrium between the proinflammatory and anti-inflammatory is essential for implantation [222]. Prior to the blastocyst arrival, the stromal cells of endometrium release proinflammatory cytokines such as TNF $\alpha$ and IL1 $\beta$ to trigger inflammatory activity [16] that can attain optimum efficiency at implantation window which is the period of an immune and inflammatory reaction [223]. The early identification of immune and inflammatory reaction initiators such as TNF $\alpha$ and IL1 $\beta$ may act as predicators of implantation [223]. TNF $\alpha$ has been found linked with the process of inflammation associated with implantation, placentation, and pregnancy outcome [224]. The uterine endometrium is always in an active state [161] The successful implantation requires the endometrium to undergo vital alterations [225]. The endometrium undergoes decidualization so that the uterus is prepared for the implantation of embryo and gestation. During the event of decidualization, the epithelium, stroma and blood vessels of the endometrium are changed into the specific tissue termed decidua [117-119]. The outcome of imperfect decidual development during the early months of gestation might be infertility or complications of pregnancy, 
for instance, preeclampsia, recurrent pregnancy loss and pre-term birth in later months of gestation [9, 99, $180,181]$.

The essential requirement for successful implantation of embryo is inflammatory reaction associated with augmented expression of various inflammatory cytokines and chemokines in endometrial cells as well as blastocyst [226]. This early inflammation related with the implantation of embryo is a physiologic response that initiates during decidualization [226]. Kosova et al. reported that RPL patients show allelic difference and variation in the expression of several cells of the immune system such as white blood cells, lymphocytes as well as the activation of $\mathrm{T}$ cells [227]. The maintenance of equilibrium between the promotion and inhibition of immunity has been proposed as an essential aspect for the development of fetus [161, 228]. The immune homeostasis and tolerance occur at decidua which is comprised of many maternally derived cells including decidual natural killer (dNK) cells, macrophages, T cells, dendritic cells, B cells and NKT cells (Table 9 ) [60, 229]. The dNK cells that originate from uNK cells primarily appear in the endometrial tissue during the luteal phase of menstrual cycle [60, 229]. These cells are mainly involved in the promotion of trophoblastic invasion and remodeling of blood vessels in order to tremendously increase the process of placental perfusion that seems to be under the regulation of chemokine and cytokine expression $[229,230]$. The main leukocytes that are present in non-pregnant stromal tissue include lymphocytes and macrophages. Towards the end of the luteal phase of endometrial cycle, the number of pheno-typically unique uNK cells and macrophages increases. During early phase of pregnancy the number of uNK cells further increases to such an extent that these cells comprise $70 \%$ of cells derived from bone marrow in the first trimester decidua of pregnancy [37]. The augmented infiltration of uNK and Foxp3 ${ }^{+}$Treg cells into the endometrium and diminished expression of PGRMC1 has been found associated with RM [231]. The hormonally responsive epithelial and stromal cell layers of endometrium show the expression of cytokine and steroid receptors as well as generate cytokines [13, 232]. The alteration in the array of decidual cytokines may well lead to spontaneous pregnancy loss [12]. The reduced IL11 expression in the endometrium of RPL patients suggests the potential role of this very cytokine in preventing miscarriages [233]. T cell cytokines may directly influence the growth and function of trophoblast cells as they express receptors for different factors including IFN $\gamma$, TNF $\alpha$, TGF $\beta$, IL6, LIF, M-CSF or they may stimulate macrophages that could assault the trophoblast. The decidual macrophages are stimulated by IFN $\gamma$ and produce NO and $\mathrm{TNF} \alpha$ that may cause pregnancy loss. The functions of macrophages and Th1 type cells may be inhibited by IL4 and IL10 cytokine that prevents the rejection of feto-allograft [234-236]. M-CSF (macrophage colony stimulating factor) acts on the trophoblastic cells and stimulates their proliferation [237]. It also triggers the process of differentiation among cyto-trophoblastic cells that as a result grow into syncytium [238]. LIF (Leukemia inhibitory factor) has a vital role in embryo implantation and development [239]. LIF is usually produced by epithelial cells of endometrium and NK cells but evidences show that this factor is additionally synthesized by certain cells which are alike to Th2 type cells. T cells of decidua have been reported to produce deficient LIF in RPL patients. Since cytokines have the property to act locally as a result the measurement of levels of cytokines produced by $\mathrm{T}$ cells at the maternal-embryonic interface show significant results as compared to the measurement of their levels in peripheral blood. Therefore, the examination of decidual $\mathrm{T}$ cells seems to present an excellent technique for the study of pregnancy loss. The diminished generation of decidual $\mathrm{T}$ cell cytokines especially IL4 and IL10 has been reported among idiopathic RPL women as compared to women with a history of normal pregnancy [82]. However, a few studies have shown association between successful pregnancy and the T cell factors such as IL4, IL10 and M-CSF produced at the materno-embryonic interface [240]. IL10 expression at materno-embryonic interface has been reported in numerous studies [24, 241,242] and this cytokine inhibits the formation and role of proinflammatory cytokines such as IL1, IL12, IFN $\gamma$ etc [243]. During normal pregnancy, the up-regulation of IL10 protein and mRNA has been found in gestational tissues [244]. IL10 as a strong factor stimulates the production of tolerogenic dendritic cells [245] which are key participants in inducing materno-immune tolerance to embryonic allo-antigens [122] and thus may promote prolific pregnancy.

T regulatory lymphocytes that produce as well as develop under the influence of IL10 also play a significant role in pregnancy success via inducing materno-immune tolerance to embryonic allo-antigens [51]. Binding of 
IL10 to IL10 receptor (IL10R) activates the IL10/JAK1/STAT3 cascade with subsequent STAT3 phosphorylation that results in STAT3 homo-dimer (STAT3/STAT3) production. The translocation of this homo-dimer into nucleus stimulates the expression of the target gene that plays a part in successful pregnancy induction [246-248]. The phosphorylated STAT3 (pSTAT3) that significantly increases in decidual Treg cells of idiopathic RPL patients inhibits Treg cell proliferation via down-regulating STAT5 and Foxp3 expression and increases the proportion of responder T cells. In addition, pSTAT3 decreases the IL10 and TGF $\beta 1$ secretion from Treg cells. The over-expression of IL6 and IL23 stimulates the phosphorylation of STAT3 in Treg cells. STAT3 hyper-phosphorylation impairs Treg cell cytokine secretion, suppression and proliferation, while the inhibition of STAT3 phosphorylation reinstates these Treg cell functions. pSTAT3 alters the balance of Treg/Th17 at the materno-embryonic interface [249]. Reduced production of IL10 together with the augmented synthesis of inflammatory molecules might be a milieu that promotes preterm birth or loss of early gestation [250]. However, the treatment of abortion-prone CBA/DBA mice with recombinant IL10 significantly abrogates the rate of spontaneous embryonic loss [251]. The human endometrial cells including epithelial, stromal and lymphoid express TNF $\alpha$ along with its mRNA [252, 253]. The endometrial TNF $\alpha$ level has been found dynamic during menstrual cycle but showing gradual rise at late luteal phase [254]. $\mathrm{TNF} \alpha$ along with IFN $\gamma$ hamper the growth of embryo and the production of trophoblastic cell lines [255] due to their cytotoxic effect on fibroblast like embryonic cells [256]. Higher level of TNF $\alpha$ and IFN $\gamma$ have been reported in circulating blood of women that undergo successive pregnancy loss than those that carry gestation successfully to full term [257, 258]. The equilibrium between IL12 and IL4 favours the response of Th1 and Th2 respectively and ultimately decides the influence of Th1/Th2 dichotomy throughout an immune reaction [259]. Furthermore, it is well understood that an earlier pregnancy loss as a result of several other etiology might induce successive Th1 biased immune responses in mother [260].

The PGD2 (Postaglandin D2) synthesized by the placenta may work as a chemo attractant of Th2 type cells to the maternal embryonic interface through the expression of typical Th2 receptor molecule CRTH2 (Chemoattractant receptor homologous molecule expressed on Th2 type cells) [261]. The cells that express CRTH2+ are decreased in number at the materno-embryonic interface among those females who experience RPL in comparison to females that undergo elective termination of pregnancy [262]. During pregnancy, infection mainly by intracellular parasites might be a significant factor responsible for driving the immune response along a specific course. Strongly Th1 predominant reactions in opposition to infectious microbes compromise gestation; for instance, the infection due to Leishmania major leads to resorption followed by simultaneous rise in placental IFN $\gamma$ level [263]. TNF $\alpha$ in coordination with hormones causes placental thrombosis in pregnancy and shows augmented synthesis with the inception of labor and pregnancy loss [264]. TNF $\alpha$ exhibits pleiotropic property and is chiefly produced by NK cells, mononuclear phagocytes, lymphocytes and antigen-stimulated T cells [265]. TNF $\alpha$ and LT $\alpha$ (lymphotoxin- $\alpha$ ) are known to produce proabortogenic effects including the invasion of trophoblasts and placentation [266] stimulation of pro-apoptotic gene expression in human embryonic membranes [267] that in turn hastens the degradation of membranes and their early rupture [268]. It also assists indirect spontaneous pregnancy loss via stimulating NK cells or macrophages [269]. The NK cells are stimulated by IFN $\gamma$ produced by Th1 type of cells and their activation might be injurious to murine conceptus [270] showing the obvious relationship of NK cells and IFN $\gamma$ in pregnancy collapse. The cytokines produced by Th2 type of cells effect NK cells in a number of ways that include inhibiting NK cell binding and vascular endothelium cytotoxicity [271], hampering the production of NK cells [272] and biasing of NK cell cytokine manufacture toward a Th2 phenotype [273, 274]. Generally, uNK cells promote invasion of trophoblasts, protect the embryo from maternal immune attack, and enhances angiogenesis [275, 276] as suggested by their close proximity with invading trophoblasts during early stage of pregnancy $[275,277]$ and production of a broad spectrum of cytokines such as TNF $\alpha$, TGF $\beta$, IFN $\gamma$, IL2, GM-CSF, LIF, CXCL10, CSF-1, and CXL12 as well as angiogenic mediators such as VEGF (vascular endothelial growth factor) and ANG2 (angiopoietin-2) on activation [278]. Additionally, uNK/dNK cells express specific receptors for HLAs (human leukocyte antigens) including KIR (killer immunoglobulin receptor), CD94/NKG2A, ILT2 which are exclusively expressed in trophoblasts $[279,280]$. This interactive collaborative between uNK/dNK and trophoblast specific HLAs is implicit as a vital potential factor implicated in the prevention of embryonic rejection by maternal immune system [281- 284]. Moreover, IL15 stimulated uNK cells are believed to play 
a key role in the maintenance of homeostasis by selectively targeting and cleaning of senescent decidual cells via granule exocytosis [285]. However, there are reports that show abnormally higher number of NK cells among females who have experienced idiopathic RPL [286]. A recent study also reported considerably higher pNK cells in pregnant women with RPL history patients as compared to normal pregnant females [287]. Most recently it has been shown that pNK cytotoxicity is significantly reduced in RPL patients than in fertile women [288]. Another most recent study depicted results contrary to previous study and reported an elevation in NK cytotoxic activity in RPL women compared to fertile women [289]. Therefore, it seems that pregnancy-promoting functions of NK cells are dysregulated in RPL patients.

Non-immune cells such as, the trophoblasts of the placenta furthermore promote the dominance of Th2 type cytokines during pregnancy [290]. Trophoblast, decidua and amnion all act as contributing factors to the Th2 type cytokine atmosphere via synthesizing IL13 [291], IL10 [292], IL4 and IL6 [293, 294]. Therefore, the production of any of these cytokines in abnormal proportions in women affected with idiopathic RPL might cause aberrant growth and role of placenta and subsequently leads to spontaneous pregnancy loss [7]. The cytokine environment in the endometrium can be regulated by $\mathrm{T}$ lymphocytes. Th2 type cytokines have been additionally reported in peri-implantation endometrium of human beings [295] and at the murine maternoembryonic interface [25], where they are thought to perform a crucial part in the uterine cytokine network of pregnancy [296] More TNF- $\alpha$ has been reported in the deciduas of RPL women who had miscarried [297] however, less in their trophoblast [298]. In human female endometrium, the augmented or suppressed Th1 immunity has been observed during habitual implantation failure [299]. This augmented Th1 type immunity might diminish the number or role of Treg cells and the decline in the Treg cell number perhaps induces implantation failure, resulting in idiopathic infertility [7].

Jasper et al. reported that primary idiopathic infertility is linked with the diminished expression of Foxp3 mRNA in the endometrial tissue [300]. Foxp3 mRNA and protein levels have been found decreased in RPL affected women. The selective Foxp3 expression in human trophoblasts suggests the association of Foxp3 expression with the trophoblast proliferation and invasion behavior. The reduced expression of Foxp3 in RPL trophoblasts may provide better insight in the RPL pathology [301]. Treg cells take part in the protection of the embryo via down-regulating inflammatory reactions. Treg cells have the potential to inhibit the production of cytokines both in CD4+T and CD8 + cells, cytotoxicity action of NK cells, as well as maturation and role of dendritic cells, which suppresses the activation of local inflammation [9, 302-304]. The lack of Treg cell mediated modulation may result in loss of pregnancy [9]. The decidua of women with RPL has been reported to show the significant expression of IL23, IL17 and retinoid orphan receptor $\mathrm{C}$ [89]. The impaired dynamics and expression of proinflammatory and implantation factor, such as IL33 [305] and prokineticin-1 [306] form the molecular basis of decidual dysfunction in RPL. IL33 regulates the factors essential for decidual receptivity during the implantation window, whereas prokineticin-1 participates in angiogenesis and regulation of decidualization and implantation processes [119]. Endometrium has been found low receptive in idiopathic RPL women [307]. Impaired differentiation of stromal cells has been reported in RPL [306]. Usually proinflammatory cytokines including TNF $\alpha$, IL1, IL6 [70] and IFN? produced by the recruited NK cells and Mo/Mph [308] are activated locally in the decidua nearly the occasion of embryo implantation. These cytokines affect the decidualization of DSCs (dendritic stromal cells) and as a result determine the crosstalk between immune and non-immune cells in the differentiating decidual environment. Later on, anti-inflammatory factors enrich the decidual niche and support the maternal immune tolerance towards the embryo [119]. The pregnancy outcome shows a close association with the activities of different biological factors especially cytokines (Table 10) whose imbalance at materno-embryonic interface may cause reproductive failure. Differences have been reported among endometrial immune cell populations of RPL women before conception and become aggravated in women who subsequently continue to miscarry [7]. This suggests that the immune network of RPL females in fact, might be compromised before the establishment of pregnancy. This nature of immune negotiation is still an arena of active research.

\section{Conclusion:}

The maternal-embryonic interface is well thought-out to be immunosuppressed so that there is the healthy 
growth of the placental-embryonic unit. The profiling of decidual cytokines and diversity of decidual cells recommends that the in vivo condition is more complicated. Cytokines are minute protein molecules that perform multiple functions. They are often derived white blood cells and described through their immune modulatory actions. The cytokines from decidua in addition to their immunosuppression role also participate in the establishment of pregnancy via regulating the invasion of trophoblasts and modifying the spiral blood arteries. Different cytokines and chemokines discharged from the decidual as well as embryonic cells at the time of implantation trigger many signaling networks between the mother and the embryo. Errors in the development of decidua during early gestational months result in pregnancy failure or later gestational complications. The management of RPL in a large proportion of cases due to the ambiguity of diagnosis is still undergoing progression. Correction of IL11 signaling in the endometrium may be one of the potential therapeutic approach for preventing infertility and miscarriage. Further exhaustive research in reproductive immunology is required with the aim to explore the detailed contribution of NK cells and Treg cells along with various cytokines and antigenic proteins to the etiology of RPL. Once a broad comprehension of the modulation of the endometrial immune atmosphere due to cytokines is developed and a molecular clue for the etiology of unexplained RPL is acquired, new, specific and effectual therapeutic protocols for patients with unexplained RPL may be well established.

\section{Acknowledgements:}

The authors are grateful to authors/editors/publishers of all those articles and journals from where the literature for this article has been reviewed. The authors are also highly obliged to Centre of Research for Development, University of Kashmir and Department of Biochemistry, Government Medical College, Srinagar.

Funding:

None

\section{Conflict of interest:}

The authors declare that they have no conflicts of interest.

\section{References:}

1. Charach R, Sheiner E, Beharier O, Sergienko R, Kessous R. Recurrent pregnancy loss and future risk of female malignancies. Arc Gynecol Obstet. (2018) 298: 781-87.

2. Ali S, Majid S, Ali MN, Taing S. Evaluation of T cell cytokines and their role in recurrent miscarriage. Int Immunopharmacol.(2020) 82: 106347. https://doi.org/10.1016/j.intimp.2020.106347

3. Ghaebi M, Nouri M, Ghasemzadeh A, Farzadi L, Jadidi-Niaragh F, Ahmadi M, Yousefi M. Immune regulatory network in successful pregnancy and reproductive failures. Biomed Pharmacother. (2017) 88: $61-73$.

4. Williams Z. Inducing tolerance to pregnancy. N Engl J Med.(2012) 367:1159- 61.

5. Somerset DA, Zheng Y, Kilby MD, Sansom DM, Drayson MT. Normal human pregnancy is associated with an elevation in the immune suppressive CD25+ CD4+ regulatory T-cell subset. Immunol. (2004) 112: 38-43.

6. Zenclussen AC, Gerlof K, Zenclussen ML, Sollwedel A, Bertoja AZ, Ritter T, Kotsch K, Leber J, Volk HD. Abnormal T-cell reactivity against paternal antigens in spontaneous abortion: adoptive transfer of pregnancy-induced CD4+ CD25 + T regulatory cells prevents fetal rejection in a murine abortion model. Am J Pathol. (2005) 166: 811-22.

7. Saini V, Arora S, Yadav A, Bhattacharjee J. Cytokines in recurrent pregnancy loss. Clin chim acta. (2011) 412: 702-8.

8. Hamor C, Monsivais D, Matzuk M. Identifying the BMP Pathway Type II Receptors in Decidualization. The FASEB Journal . (2019) 33:476-9.

9. Mori M, Bogdan A, Balassa T, Csabai T, Szekeres-Bartho J. The decidua - the maternal bed embracing the embryo - maintains the pregnancy. In Sem Immunopathol . (2016) 38: 635-49. 
10. Szwarc MM, Hai L, Gibbons WE, Mo Q, Lanz RB, DeMayo FJ, Lydon JP. Early growth response 1 transcriptionally primes the human endometrial stromal cell for decidualization. J Steroid Biochem Mol Biol.(2019)189: 283-90.

11. Soczewski E, Grasso E, Gallino L, Hauk V, Fernández L, Gori S, Paparini D, Leirós CP, Ramhorst R. Immunoregulation of the decidualization program: focus on the endoplasmic reticulum stress. Reprod . (2020)159: R203-11.

12. Lash GE, Ernerudh J. Decidual cytokines and pregnancy complications: focus on spontaneous miscarriage. J Reprod Immunol. (2015) 108: 83-89.

13. Tabibzadeh S. Human endometrium: an active site of cytokine production and action. Endocr Rev. (1991) 12: 272-90.

14. Vignali D. How many mechanisms do regulatory T cells need? Eur J Immunol. (2008) 38:908-11.

15. Liu J, Hao S, Chen X, Zhao H, Du L, Ren H, Wang C, Mao H. Human placental trophoblast cells contribute to maternal-fetal tolerance through expressing IL-35 and mediating iT R 35 conversion. Nat Comm. (2019) 10:1-0.

16. Hinduja I, Pathare ADS, Zaveri K. Immunological approach of personalized treatment for recurrent implantation failure patients undergoing IVF. Glob J Reprod Med. (2018) 5.

17. MUÑOZ OB, Martínez-Vega RA, Torres-Yepes K, Olivares EG Cytokine secretion by endometrial stromal human cells from menstruation and decidua stromal human cells from placentas collected of vaginal and caesarean deliveries. Front Immunol. (2015). doi: 10.3389/conf.fimmu.2015.05.00104

18. Woodworth CD, Simpson S. Comparative lymphokine secretion by cul-tured normal human cervical keratinocytes, papillomavirus-immortalized, and carcinoma cell lines. Am J Pathol. (1993)142: 1544-55.

19. Fichorova RN, Anderson DJ. Differential expression of immunobiological mediators by immortalized human cervical and vaginal epithelial cells.Biol Reprod. (1999) 60: 508-14.

20. Grant KS, Wira CR Effect of mouse uterine stromal cells on epithelial cell transepithelial resistance (TER) and TNF $\alpha$ and TGF $\beta$ release in culture. Biol Reprod. (2003) 69:1091-8.

21. Fahey JV, Schaefer TM, Channon JY, Wira CR. Secretion of cytokines and chemokines by polarized human epithelial cells from the female reproductive tract. Hum Reprod. (2005) 20:1439-46.

22. Mosmann TR, Cherwinski H, Bond MW, Giedlin MA, Coffman RL. Two types of murine helper T cell clone. I. Definition according to profiles of lymphokine activities and secreted proteins. J Immunol. (1986) 136: 2348-57.

23. Chaouat, G., Menu, E., Clark, D.A., Dy, M., Minkowski, M. and Wegmann,T.G. (1990) Control of fetal survival in CBA x DBA/2 mice bylymphokine therapy. J Reprod Fertil. (89) 447-58.

24. Lin H, Mosmann MT, Guilbert L, Tuntipopipat S, Wegmann TG. Synthesis of T helper 2-type cytokines at the maternal-fetal interface. J Immunol. (1993) 151:4562-73.

25. Wegmann TG, Lin H, Guilbert L, Mosmann TR. Bidirectional cytokine interactions in the maternalfetal relationship: is successful pregnancy a TH2 phenomenon? Immunol Today. (1993) 14:353-6.

26. Lidstrom C, Matthiesen L, Berg G, Sharma S, Ernerudh J, Ekerfelt C: Cytokine secretion patterns of NK cells and macrophages in early human pregnancy decidua and blood: implications for suppressor macrophages in decidua. Am J Reprod Immunol. (2003) 50: 444- 52.

27. Renaud SJ, Graham CH: The role of macrophages in utero-placental interactions during normal and pathological pregnancy. Immunol Invest. (2008) 37: 535- 64.

28. Lash GE, Robson SC, Bulmer JN: Review: Functional role of uterine natural killer (uNK) cells in human early pregnancy decidua.Placenta. (2010) 31 Suppl: S87-S92.

29. Lee SK, Kim CJ, Kim DJ, Kang JH. Immune Cells in the Female Reproductive Tract. Immune Netw. (2015) 15: 16-26.

30. Lee JY, Lee M, Lee SK. Role of Endometrial Immune Cells in Implantation. Clin Exp Reprod Med. (2011) 38:119-25.

31. Harrity C, Bereir MM, Walsh DJ, Marron KD. Moving from Peripheral Blood to Local Uterine Immunophenotype Analysis in Patients with Poor Reproductive History: Pilot Study of a Novel Technique. Ir J Med Sci. (2019) 188: 893-901.

32. Flynn L, Byrne B, Carton J, Kelehan P, O'Herlihy C, O'Farrelly C. Menstrual Cycle Dependent 
Fluctuations in NK and T-Lymphocyte Subsets from Non-Pregnant Human Endometrium. Am $J$ Reprod Immunol.(2000) 43: 209-17.

33. Lee S, Kim J, Jang B, Hur S, Jung U, Kil K, Na B, Lee M, Choi Y, Fukui A, Gilman-Sachs A. Fluctuation of peripheral blood T, B, and NK cells during a menstrual cycle of normal healthy women. J Immunol.(2010) 185:756-62

34. Zenclussen AC, Hammerling GJ. Cellular Regulation of the Uterine Microenvironment That Enables Embryo Implantation. Front Immunol. (2015) 6: 321.

35. Salamonsen LA, Lathbury LJ. Endometrial Leukocytes and Menstruation.Hum Reprod Update. (2000) 6: $16-27$.

36. Robertson SA, Moldenhauer LM. Immunological Determinants of Implantation Success. Int J Dev Biol. (2014) 58: 205-17.

37. King A. Uterine Leukocytes and Decidualization. Hum Reprod Update. (2000) 6:28-36.

38. Schulke L, Manconi F, Markham R, Fraser IS. Endometrial Dendritic Cell Populations During the Normal Menstrual Cycle. Hum Reprod.(2008) 23: 1574-80

39. Ramhorst R, Grasso E, Paparini D, Hauk V, Gallino L, Calo G, Vota D, Perez Leiros C. Decoding the Chemokine Network that Links Leukocytes with Decidual Cells and the Trophoblast During Early Implantation. Cell Adh Migr. (2016) 10: 197-207.

40. Rieger L, Honig A, Sutterlin M, Kapp M Dietl J, Ruck P, Kammerer U. Antigen-Presenting Cells in Human Endometrium During the Menstrual Cycle Compared to Early Pregnancy. J Soc Gynecol Invest. (2004) 11: 488-93

41. Maridas DE, Hey-Cunningham AJ, Ng CHM, Markham R, Fraser IS, Berbic M. Peripheral and Endometrial Dendritic Cell Populations During the Normal Cycle and in the Presence of Endometriosis. J Endometr Pelvic Pain Disord. (2014) 6: 67-119.

42. Zenclussen AC, Olivieri DN, Dustin ML, Tadokoro CE. In Vivo Multiphoton Microscopy Technique to Reveal the Physiology of the Mouse Uterus. Am J Reprod Immunol. (2013) 69: 281-89.

43. Okada H, Tsuzuki T, Murata H. Decidualization of the Human Endometrium. Reprod Med Biol. (2018) 17: 220-27.

44. Drury JA, Parkin KL, Coyne L, Giuliani E, Fazleabas AT, Hapangama DK. The Dynamic Changes in the Number of Uterine Natural Killer Cells are Specific to the Eutopic but not to the Ectopic Endometrium in Women and in a Baboon Model of Endometriosis. Reprod Biol Endocrinol.(2018) 16: 67.

45. Manaster I, Mizrahi S, Goldman-Wohl D, Sela HY Stern-Ginossar N, Lankry D, Gruda R, Hurwitz A, Bdolah Y, Haimov-Kochman R, et al. Endometrial NK Cells are Special Immature Cells that Await Pregnancy.J Immunol. (2008) 181: 1869-76.

46. Fukui A, Funamizu A, Fukuhara R, Shibahara H. Expression of Natural Cytotoxicity Receptors and Cytokine Production on Endometrial Natural Killer Cells in Women with Recurrent Pregnancy Loss or Implantation Failure, and the Expression of Natural Cytotoxicity Receptors on Peripheral Blood Natural Killer Cells in Pregnant Women with a History of Recurrent Pregnancy Loss. J Obstet Gynaecol Res. (2017) 43: 1678-86

47. Chang HF, Bzeih H, Chitirala P, Ravichandran K, Sleiman M, Krause E, Hahn U, Pattu V, Rettig J. Preparing the Lethal Hit: Interplay Between Exo-And Endocytic Pathways in Cytotoxic T Lymphocytes. Cell Mol Life Sci. (2017) 74: 399-408

48. Zhao X, Jiang Y, Wang L, Li Z, Li Q, Feng X. Advances in Understanding the Immune Imbalance between T-Lymphocyte Subsets and NK Cells in Recurrent Spontaneous Abortion. Geburtshilfe Frauenheilkd.(2018) 78: 677-83.

49. Sasaki Y, Sakai M, Miyazaki S, Higuma S, Shiozaki A, Saito S. Decidual and Peripheral Blood CD4+CD25+ Regulatory T Cells in Early Pregnancy Subjects and Spontaneous Abortion Cases. Mol Hum Reprod. (2004) 10:347-53.

50. Roberton SA, Care AS, Moldenhauer LM. Regulatory T Cells in Embryo Implantation and the Immune Response to Pregnancy. J Clin Invest . (2018) 128: 4224-35.

51. Alijotas-Reig J, Llurba E, Gris JM. Potentiating Maternal Immune Tolerance in Pregnancy: A New 
Challenging Role for Regulatory T Cells.Placenta. (2014) 35: 241-48.

52. Arruvito L, Sanz M, Banham AH, Fainboim L. Expansion of CD4+CD25+and FOXP3+Regulatory T Cells During the Follicular Phase of the Menstrual Cycle: Implications for Human Reproduction. $J$ Immunol. (2007) 178: 2572-78.

53. Kofod L, Lindhard A, Hviid TVF. Implications of Uterine NK Cells and Regulatory T Cells in the Endometrium of Infertile Women. Hum Immunol. (2018) 79: 693-701

54. Vanderstraeten A, Tuyaerts S, Amant F. The Immune System in the Normal Endometrium and Implications for Endometrial Cancer Development.J Reprod Immunol. (2015) 109: 7-16.

55. Nadkarni S, Smith J, Sferruzzi-Perri AN, Ledwozyw A, Kishore M, Haas R, Mauro C, Williams DJ, Farsky SHP, Marelli-Berg FM, et al. Neutrophils Induce Proangiogenic T Cells with a Regulatory Phenotype in Pregnancy. Proc Natl Acad Sci. USA (2016) 113: E8415-E8424

56. King AE, Critchley HOD, Kelly RW. Innate Immune Defences in the Human Endometrium. Reprod Biol Endocrinol. (2003) 1: 116.

57. Armstrong GM, Maybin JA, Murray AA, Nicol M, Walker C, Saunders PTK, Rossi AG, Critchley HOD. Endometrial Apoptosis and Neutrophil Infiltration During Menstruation Exhibits Spatial and Temporal Dynamics that are Recapitulated in a Mouse Model. Sci Rep.(2017) 12:17416

58. Faas MM, De Vos P. Innate Immune Cells in the Placental Bed in Healthy Pregnancy and Preeclampsia. Placenta ( 2018) 69:125-33.

59. Tsao FY, Wu MY, Chang YL, Wu CT, Ho HN. M1 Macrophages Decrease in the Deciduae from Normal Pregnancies but not from Spontaneous Abortions or Unexplained Recurrent Spontaneous Abortions. J Formos Med Assoc. (2018) 117, 204-11.

60. Erlebacher A. Immunology of the Maternal-Fetal Interface. Annu Rev Immunol. (2013) 31: 387-411.

61. Care AS, Diener KR, Jasper MJ, Brown HM, Ingman WV, Robertson SA. Macrophages Regulate Corpus Luteum Development During Embryo Implantation in Mice. J Clin Invest. (2013) 123: 347287.

62. Jeziorska M, Salamonsen LA, Woolley DE. Mast Cell and Eosinophil Distribution and Activation in Human Endometrium Throughout the Menstrual Cycle. Biol Reprod. (1995) 53: 312-20.

63. De Leo B, Esnal-Zufiaurre A, Collins F, Critchley HOD, Saunders PTK. Immunoprofiling of Human Uterine Mast Cells Identifies Three Phenotypes and Expression of ER $\beta$ and Glucocorticoid Receptor.F1000Res. (2017) 6: 667.

64. Murphy SP, Tayade C, Ashkar AA, Hatta K, Zhang J, Croy BA. Interferon gamma in successful pregnancies. Biol Reprod. (2009) 80: 848-59.

65. Piccinni MP, Scaletti C, Maggi E, Romagnani S. Role of hormone-controlled Th1- and Th2-type cytokines in successful pregnancy. J Neuroimmunol. (2000) 109: 30-3.

66. Drake PM, Gunn MD, Charo IF, Tsou CL, Zhou Y, Huang L, Fisher SJ. Human placental cytotrophoblasts attract monocytes and CD56 (bright) natural killer cells via the actions of monocyte inflammatory protein 1alpha. J Exp Med. (2001) 193: 1199-1212.

67. Dimitriadis E, White CA, Jones RL, Salamonsen LA. Cytokines, chemokines and growth factors in endometrium related to implantation.Hum Reprod Update. (2005) 11: 613-30.

68. Lash GE, Schiessl B, Kirkley M, Innes BA, Cooper A, Searle RF, Robson SC, Bulmer JN. Expression of angiogenic growth factors by uterine natural killer cells during early pregnancy. J Leukoc Biol.(2006) 80: $572-80$.

69. Aplin JD. The cell biological basis of human implantation. Best Pract Res Clin Obstet Gynaecol . (2000) 14: 757-64.

70. Van Mourik MSK, Macklon NS, Heijnen CJ. Embryonic implantation: cytokines, adhesion molecules and immune cells in establishing an implantation environment. J Leukocyt Biol. (2009) 85:4-19.

71. Romagnani S. Human Th1 and Th2: doubt no more. Immunol Today.(1991) 12:256-7.

72. Erdmann AA, Jung U, Foley JE, Toda Y, Fowler DH. Co-stimulated/Tc2 cells abrogate murine marrow graft rejection. Biol Blood Marrow Transp. (2004) 10: 604-13.

73. Burns WR, Wang Y, Tang PC, Ranjbaran H, Iakimov A, Kim J, Cuffy M, Bai Y, Pober JS, Tellides G. Recruitment of CXCR3+ and CCR5 + T Cells and Production of Interferon- $\gamma$-Inducible Chemokines 
in Rejecting Human Arteries. Am J Transp. (2005) 5:1226-36.

74. Nickerson P, Steurer W, Steiger J, Zheng X, Steele AW, Strom TB. Cytokines and the Th1/Th2 paradigm in transplantation. Curr Opin Immunol. (1994) 6:757-64.

75. Strom TB, Roy-Chaudhury P, Manfro R, Xheng XX, Nickerson PW, Wood K, Bushell A. The Th1/Th2 paradigm and the allograft response. Curr Opin Immunol. (1996) 8:688-93.

76. Li XC, Zand MS, Li Y, Zheng XX, StromTB. On histocompatibility barriers, Th1 to Th2 immune deviation, and the nature of the allograft responses. J Immunol .(1998) 161:2241-7

77. Ashkar AA, Di Santo JP, Croy BA. Interferon gamma contributes to initiation of uterine vascular modification, decidual integrity, and uterine natural killer cell maturation during normal murine pregnancy. $J$ Exp Med. (2000) 192: 259-70.

78. Croy BA, Esadeg S, Chantakru S, Van Den Heuvel M, Paffaro VA, He H, Black GP, Ashkar AA, Kiso Y, Zhang J. Update on pathways regulating the activation of uterine Natural Killer cells, their interactions with decidual spiral arteries and homing of their precursors to the uterus. J Reprod Immunol. (2003) 59: $175-91$.

79. Robson A, Harris LK, Innes BA, Lash GE, Aljunaidy MM, Aplin JD, Baker PN, Robson SC, Bulmer JN. Uterine natural killer cells initiate spiral artery remodeling in human pregnancy. FASEB J. (2012) 26: $4876-85$.

80. Fallon PG, Jolin HE, Smith P, Emson CL, Townsend MJ, Fallon R, Smith P, McKenzie AN. IL-4 induces characteristic Th2 responses even in the combined absence of IL-5, IL-9, and IL-13. Immunity. (2002) $17: 7-17$.

81. Saito S, Nakashima A, Shima T, Ito M. Th1Th2Th17 and regulatory T-cell paradigm in pregnancy. Am J Reprod Immunol . (2010) 63: 601-10

82. Piccinni MP, Beloni L, Livi C, Maggi E, Scarselli G, Romagnani S. Defective production of both leukemia inhibitory factor and type $2 \mathrm{~T}$-helper cytokines by decidual $\mathrm{T}$ cells in unexplained recurrent abortions. Nat Med. (1998) 4:1020-24.

83. Raghupathy R. Th1-type immunity is incompatible with successful pregnancy. Immunol Today. (1997) 18:478-82.

84. Chaouat G, Lédée-Bataille N, Zourbas S, Ostojic S, Dubanchet S, Martal J, Frydman R. Cytokines, implantation and early abortion: re-examining the Th1/Th2 paradigm leads to question the single pathway, single therapy concept. Am J Reprod Immunol . (2003) 50:177-86.

85. Bates MD, Quenby S, Takakuwa K, Johnson PM, Vince GS. Aberrant cytokine production by peripheral blood mononuclear cells in recurrent pregnancy loss? Hum Reprod. (2002) 17:2439-44.

86. Chaouat G, Zourbas S, Ostojic S, Lappree-Delage G, Dubanchet S, Ledee N, Martal J. A brief review of recent data on some cytokine expressions at the materno-foetal interface which might challenge the classical Th1/Th2 dichotomy. J Reprod Immunol. (2002) 53: 241-56.

87. Peck A, Mellins ED. Plasticity of T-cell phenotype and function: the T helper type 17 example. Immunol. (2010) 129:147-53.

88. Crome SQ, Wang AY, Levings MK. Translational mini-review series on Th17 cells: function and regulation of human T helper 17 cells in health and disease. Clin Exp Immunol. (2010) 159:109-19.

89. Lee SK, Kim JY, Lee M, Gilman Sachs A, Kwak Kim J. Th17 and regulatory T cells in women with recurrent pregnancy loss. Am J Reprod Immunol . (2012) 67: 311-8.

90. Steinborn A, Schmitt E, Kisielewicz A, Rechenberg S, Seissler N, Mahnke K, Schaier M, Zeier M, Sohn C. Pregnancy associated diseases are characterized by the composition of the systemic regulatory $\mathrm{T}$ cell (Treg) pool with distinct subsets of Tregs. Clin Exp Immunol. ( 2012) 167: 84-98.

91. Wang WJ, Hao CF, Qu QL, Wang X, Qiu LH, Lin QD. The deregulation of regulatory T cells on interleukin-17-producing $\mathrm{T}$ helper cells in patients with unexplained early recurrent miscarriage. Hum Reprod. (2010) 25: 2591-6.

92. Corthay A. How do regulatory T cells work? Scand J Immunol.(2009) 70: 326-36.

93. Saito S, Sasaki Y, Sakai M. CD4 (+) CD25 high regulatory T cells in human pregnancy. J Reprod Immunol. ( 2005) 65: 111-20.

94. Keller CC, Eikmans M, van der Hoorn ML, Lashley LE. Recurrent miscarriages and the association 
with regulatory T cells; a systematic review. J Reprod Immunol. (2020) 103105.

95. Ruocco MG, Chaouat G, Florez L, Bensussan A, Klatzmann D. Regulatory T-cells in pregnancy: historical perspective, state of the art, and burning questions. Front Immunol. (2014) 5 : 389, doi:10.3389/fimmu.2014.00389

96. Erlebacher A. Mechanisms of T cell tolerance towards the allogeneic fetus. Nat Rev Immunol. (2013) $13: 23-33$.

97. Robertson SA, Prins JR, Sharkey DJ, Moldenhauer LM. Seminal fluid and the generation of regulatory T cells for embryo implantation. Am J Reprod Immunol. ( 2013) 69: 315-30.

98. Zenclussen AC. Adaptive immune responses during pregnancy. Am J Reprod Immunol. (2013) 69:291303.

99. Prabhu Das M, Bonney E, Caron K, Dey SCA, Fazleabas A, et al. Immune mechanisms at the maternal-fetal interface: perspectives and challenges. Nat Immunol. (2015) 16:328-34.

100. Saito S, Nakabayashi Y, Nakashima A, Shima T, Yoshino O. A new era in reproductive medicine: consequences of third-party oocyte donation for maternal and fetal health. Semin Immunopathol. (2016) 38:687-97.

101. Saito S, Shima T, Nakashima A, Inada K, Yoshino O. Role of paternal antigen-specific treg cells in successful implantation. Am J Reprod Immunol. (2016) 75:310-6.

102. Wang WJ, Hao CF, Yin GJ, Bao SH, Qiu LH, Lin QD. Increased prevalence of T helper 17 (Th17) cells in peripheral blood and decidua in unexplained recurrent spontaneous abortion patients. $J$ Reprod Immunol. (2010) 84:164-70.

103. Nakashima A, Ito M, Shima T, Bac ND, Hidaka T, Saito S. Accumulation of IL-17-positive cells in decidua of inevitable abortion cases.Am J Reprod Immunol. (2010) 64:4-11.

104. Wu HX, Jin LP, Xu B, Liang SS, Li DJ. Decidual stromal cells recruit Th17 cells into decidua to promote proliferation and invasion of human trophoblast cells by secreting IL-17. CellMol Immunol. (2014) 11: 253-62.

105. Liu YS, Wu L, Tong XH, Wu LM, He GP, Zhou GX, Luan HB. Study on the relationship between Th17 cells and unexplained recurrent spontaneous abortion. Am J Reprod Immunol . (2011) 65: 503-11.

106. Abdolmohammadi Vahid S, Ghaebi M, Ahmadi M, Nouri M, Danaei S, Aghebati-Maleki L, Mousavi Ardehaie R, Yousefi B, Hakimi P, Hojjat-Farsangi M, Rikhtegar R. Altered T-cell subpopulations in recurrent pregnancy loss patients with cellular immune abnormalities. $J$ Cellul Physiol. (2019): 234:4924-33.

107. Raghupathy R, Makhseed M, Azizieh F, Hassan N, Al-Azemi M, Al-Shamali E. Maternal Th1- and Th2-type reactivity to placental antigens in normal human pregnancy and unexplained recurrent spontaneous abortions. Cell Immunol. (1999) 196:122-30. 10.1006/cimm.1999.1532

108. Kwak JY, Beaman KD, Gilman-Sachs A, Ruiz J, Shewitz D, Beer AE,. Up-regulated expression of CD56+, CD56+/CD16+, and CD19+ cells in peripheral blood lymphocytes in pregnant women with recurrent pregnancy losses. Am J Reprod. Immunol. (1995) 34: 93-99.

109. Kwak-Kim JY, Chung-Bang HS, Ng SC, Ntrivalas EI, Mangubat CP, Beaman KD, Beer AE, GilmanSachs A. Increased $\mathrm{T}$ helper 1 cytokine responses by circulating $\mathrm{T}$ cells are present in women with recurrent pregnancy losses and in infertile women with multiple implantation failures after IVF. Hum Reprod. (2003)18:767-73.

110. Veenstra van Nieuwenhoven AL, Heineman MJ, Faas MM. The immunology of successful pregnancy. Hum Reprod Update . (2003) 9: 347-57.

111. Beer AE, Kwak JY, Ruiz JE. Immunophenotypic profiles of peripheral blood lymphocytes in women with recurrent pregnancy losses and in infertile women with multiple failed in vitro fertilization cycles.Am Reprod Immunol. (1996) 35: 376-82.

112. Ruiz JE, Kwak JY, Baum L, Gilman-Sachs A, Beaman KD, Kim YB, Beer AE. Intravenous immunoglobulin inhibits natural killer cell activity in vivo in women with recurrent spontaneous abortion. Am J Reprod Immunol. (1996) 35: 370-75.

113. Dong P, Wen X, Liu J, Yan CY, Yuan J, Luo LR, Hu QF, Li J. Simultaneous detection of decidual Th1/Th2 and NK1/NK2 immunophenotyping in unknown recurrent miscarriage using 8-color flow 
cytometry with FSC/Vt extended strategy. Biosc Rep. (2017) 37.

114. Yuan J, Li J, Huang SY, Sun X. Characterization of the subsets of human NKT-like cells and the expression of Th1/Th2 cytokines in patients with unexplained recurrent spontaneous abortion. $J$ Reprod Immunol. (2015) 110:81-8.

115. Sereshki N, Gharagozloo M, Ostadi V, Ghahiri A, Roghaei MA, Mehrabian F, Andalib AA, Hassanzadeh A, Hosseini H, Rezaei A. Variations in T-helper 17 and regulatory T cells during the menstrual cycle in peripheral blood of women with recurrent spontaneous abortion.Int J Fertil Steril. (2014) 8:59.

116. Deshmukh H, Way SS. Immunological basis for recurrent fetal loss and pregnancy complications. Annual Review of Pathology: Mech Dis. (2019)14:185-210.

117. Brosens JJ, Pijnenborg R, Brosens IA. The myometrial junctional zone spiral arteries in normal and abnormal pregnancies: a review of the literature. Am J Obstet Gynecol. (2002) 187: 1416-23.

118. Gellersen B, Brosens JJ. Cyclic decidualization of the human endometrium in reproductive health and failure. Endocr Rev.(2014) 35: 851-905.

119. Vinketova K, Mourdjeva M, Oreshkova T. Human decidual stromal cells as a component of the implantation niche and a modulator of maternal immunity. J Preg. (2016) 2016: 1-17.

120. Brosens JJ. Gellersen B. Death or survival - progesterone-dependent cell fate decisions in the human endometrial stroma. J Mol Endocrinol . (2006) 36: 389-98.

121. Maldonado-P'erez D, Evans J, Denison F, Millar RP, Jabbour HN. Potential roles of the prokineticins in reproduction. Trends Endocrinol Metabol . (2007) 18: 66-72.

122. Schumacher A, Costa SD, Zenclussen AC. Endocrine factors modulating immune responses in pregnancy. Front Immunol . (2014) 5:196.

123. Santner-Nanan B, Peek MJ, Khanam R, Richarts L, Zhu E, Fazekas de St Groth B, Nanan R: Systemic increase in the ratio between Foxp3+ and IL-17-producing CD4+ T cells in healthy pregnancy but not in preeclampsia. J Immunol. (2009) 183: 7023- 30.

124. Nakashima A, Ito M, Yoneda S, Shiozaki A, Hidaka T, Saito S: Circulating and decidual Th17 cell levels in healthy pregnancy.Am J Reprod Immunol. (2010) 63: 104- 9.

125. Toldi G, Molvarec A, Stenczer B, Muller V, Eszes N, Bohacs A, Bikov A, Rigo J Jr, Vasarhelyi B, Losonczy G, Tamasi L: Peripheral Th1/Th2/Th17/regulatory T-cell balance in asthmatic pregnancy.Int Immunol. (2011) 23: 669- 77.

126. Berbic M, Hey-Cunningham AJ, Ng C, Tokushige N, Ganewatta S, Markham R, Russell P, Fraser IS: The role of Foxp3+ regulatory T-cells in endometriosis: a potential controlling mechanism for a complex, chronic immunological condition. Hum Reprod. (2010) 25: 900- 7.

127. Xiong H, Zhou C, Qi G: Proportional changes of CD4+CD25+Foxp3+ regulatory T cells in maternal peripheral blood during pregnancy and labor at term and preterm. Clin Invest Med. ( 2010) 33: E422.

128. Steinborn A, Haensch GM, Mahnke K, Schmitt E, Toermer A, Meuer S, Sohn C: Distinct subsets of regulatory $\mathrm{T}$ cells during pregnancy: is the imbalance of these subsets involved in the pathogenesis of preeclampsia? Clinical Immunol . (2008) 129: 401- 12

129. Toldi G, Rigo J Jr, Stenczer B, Vasarhelyi B, Molvarec A: Increased prevalence of IL-17-producing peripheral blood lymphocytes in pre-eclampsia. Am J Reprod Immunol (2011) 66: 223-229.

130. Hanna J, Goldman-Wohl D, Hamani Y, et al. Decidual NK cells regulate key developmental processes at the human fetal-maternal interface.Nat Med. (2006) 12: 1065-74.

131. Quenby S, Nik H, Innes B, et al. Uterine natural killer cells and angiogenesis in recurrent reproductive failure. Hum Reprod. (2009) 24: 45-54.

132. Godbole G, Modi D. Regulation of decidualization, interleukin-11 and interleukin-15 by homeobox A 10 in endometrial stromal cells. J Reprod Immunol. (2010) 85: 130-39.

133. Ashkar AA, Black GP, Wei QX, et al. Assessment of requirements for IL-15 and IFN regulatory factors in uterine NK cell differentiation and function during pregnancy. J Immunol. ( 2003) 171: 2937-44.

134. Kuroda K. Impaired endometrial function and unexplained recurrent pregnancy loss. Hypert Res Preg. (2019):HRP2018-012.

135. Nallasamy S, Kaya Okur HS, Bhurke A, Davila J, Li Q, Young SL, Taylor RN, Bagchi MK, Bagchi IC. 
Msx homeobox genes act downstream of BMP2 to regulate endometrial decidualization in mice and in humans. Endocrinol . (2019) 160: 1631-44.

136. Su Y, Guo S, Liu C, Li N, Zhang S, Ding Y, Chen X, He J, Liu X, Wang Y, Gao R. Endometrial pyruvate kinase M2 is essential for decidualization during early pregnancy. J Endocrinol. (2020) 1 (aop).

137. Neff AM, Yu J, Taylor RN, Bagchi IC, Bagchi MK. Insulin signaling via progesterone-regulated insulin receptor substrate 2 is critical for human uterine decidualization. Endocrinol. (2020) 161:bqz021.

138. Yang Y, Zhang D, Qin H, Liu S, Yan Q. poFUT1 promotes endometrial decidualization by enhancing the O-fucosylation of Notch1.EBioMed . (2019) 44: 563-73.

139. Oestreich AK, Chadchan SB, Popli P, Medvedeva A, Rowen MN, Stephens CS, Xu R, Lydon JP, Demayo FJ, Jungheim ES, Moley KH. The autophagy gene Atg16L1 is necessary for endometrial decidualization.Endocrinol. (2020) 161:bqz039.

140. Tamura I, Takagi H, Doi-Tanaka Y, Shirafuta Y, Mihara Y, Shinagawa M, Maekawa R, Taketani T, Sato S, Tamura H, Sugino N. Wilms tumor 1 regulates lipid accumulation in human endometrial stromal cells during decidualization. J Biol Chem. (2020) 295:4673-83.

141. Berkhout RP, Lambalk CB, Repping S, Hamer G, Mastenbroek S. Premature expression of the decidualization marker prolactin is associated with repeated implantation failure. Gynecol Endocrinol . (2019) :1-5.

142. Oestreich AK, Chadchan SB, Medvedeva A, Lydon JP, Jungheim ES, Moley KH, Kommagani R. The autophagy protein, FIP200 (RB1CC1) mediates progesterone responses governing uterine receptivity and decidualization. Biol Reprod. (2020).

143. Chobotova K, Karpovich N, Carver J, Manek S, Gullick WJ, Barlow DH, Mardon HJ. Heparin-binding epidermal growth factor and its receptors mediate decidualization and potentiate survival of human endometrial stromal cells. J Clin Endocrinol Metabol. (2005) 90:913-9.

144. Tan Y, Li M, Cox S, Davis MK, Tawfik O, Paria BC, Das SK. HB-EGF directs stromal cell polyploidy and decidualization via cyclin D3 during implantation. Develop Biol. (2004) 265:181-95.

145. Xie H, Wang H, Tranguch S, Iwamoto R, Mekada E, DeMayo FJ, Lydon JP, Das SK, Dey SK. Maternal heparin-binding-EGF deficiency limits pregnancy success in mice. Proceed National Acad Sci. (2007) 104:18315-20.

146. Yu HF, Duan CC, Yang ZQ, Wang YS, Yue ZP, Guo B. HB-EGF Ameliorates Oxidative StressMediated Uterine Decidualization Damage. Oxidat Med Cellul Longev. (2019) 2019.

147. Babayev SN, Kanchwala M, Xing C, Akgul Y, Carr BR, Word RA. Thrombin Alters Human Endometrial Stromal Cell Differentiation During Decidualization. Reprod Sci. (2019) 26 :278-88.

148. Mei J, Yan Y, Li SY, Zhou WJ, Zhang Q, Li MQ, Sun HX. CXCL16/CXCR6 interaction promotes endometrial decidualization via the PI3K/AKT pathway. Reprod. (2019)157:273-82.

149. Jiang Y, Li J, Li G, Lin X, He Y, Lu J, Zhang Y, Wu J, Yang Z, Jiang Y, Wang H. Osteoprotegerin (OPG) Interacts with Syndecan-1 to Mediate Human Endometrial Stromal Decidualization via Decreasing Akt Phosphorylation. (2019).

150. Lv S, Wang N, Ma J, Li WP, Chen ZJ, Zhang C. Impaired decidualization caused by downregulation of circadian clock gene BMAL1 contributes to human recurrent miscarriage. Biol Reprod. (2019) 101:138-47.

151. Vallejo G, Mestre-Citrinovitz AC, Winterhager E, Saragueta PE. CSDC2, a cold shock domain RNAbinding protein in decidualization. J Cellul Physiol . (2019) 234:740-8.

152. Xu Y, Lu J, Wu J, Jiang R, Guo C, Tang Y, Wang H, Kong S, Wang S. HOXA10 co-factor MEIS1 is Required for the Decidualization in Human Endometrial Stromal Cell. J Mol Endocrinol. (2020) 1.

153. Garrido-Gomez T, Quinonero A, Dominguez F, Rubert L, Perales A, Hajjar KA, Simon C. Preeclampsia: a defect in decidualization is associated with deficiency of Annexin A2. Am J Obstet Gynecol. (2019).

154. Windsperger K, Dekan S, Pils S, Golletz C, Kunihs V, Fiala C, Kristiansen G, Knofler M, Pollheimer J. Extravillous trophoblast invasion of venous as well as lymphatic vessels is altered in idiopathic, recurrent, spontaneous abortions. Hum Reprod.(2017) 32:1208-17. 
155. Pan-Castillo B, Gazze SA, Thomas S, Lucas C, Margarit L, Gonzalez D, Francis LW, Conlan RS. Morphophysical dynamics of human endometrial cells during decidualization. Nanomed: Nanotechnol Biol and Med. (2018) 14: 2235-45.

156. Brar AK, Handwerger S, Kessler CA, Aronow BJ. Gene induction and categorical reprogramming during in vitro human endometrial fibroblast Decidualization. Physiol Genom. (2001) 7:135-48.

157. Evans J, Catalano RD, Morgan K, Critchley HOD, Millar RP, Jabbour HN. Prokineticin 1 signaling and gene regulation in early human pregnancy.Endocrinol. (2008) 149:2877-87.

158. Takano M, Lu Z, Goto T, Fusi L, Higham J, Francis J, Withey A, Hardt J, Cloke B, Stavropoulou AV, Ishihara O. Transcriptional cross talk between the forkhead transcription factor forkhead box O1A and the progesterone receptor coordinates cell cycle regulation and differentiation in human endometrial stromal cells. Mol Endocrinol. (2007) 21: 2334-49.

159. Garrido-Gomez T, Dominguez F, Lopez JA, Camafeita E, Quinonero A, Martinez-Conejero JA, Pellicer A, Conesa A, Simon C. Modeling human endometrial decidualization from the interaction between proteome and secretome. J Clin Endocrinol Metabol . (2011) 96:706-16.

160. Popovici RM, Kao LC, Giudice LC. Discovery of new inducible genes in invitro decidualized human endometrial stromal cells using microarray technology. Endocrinol. (2000) 141: 3510-3.

161. Krieg S, Westphal L. Immune function and recurrent pregnancy loss.Semin Reprod Med. (2015) 33:30512.

162. Lowe JS, Anderson PG. Stevens \& Lowe's Human Histology E-Book.Elsev Heal Sci. (2014).

163. Das SK. Cell cycle regulatory control for uterine stromal cell decidualization in implantation. Reprod. (2009) 137:889-99.

164. Ma X, Gao F, Rusie A, Hemingway J, Ostmann AB, Sroga JM, Jegga AG, Das SK. Decidual cell polyploidization necessitates mitochondrial activity. PLoS One. (2011) 6: 1-17.

165. Dimitriadis E, Robb L, Salamonsen LA. Interleukin 11 advances progesterone-induced decidualization of human endometrial stromal cells. Mol Hum Reprod. (2002) 8: 636-43.

166. Marwood M, Visser K, Salamonsen LA, Dimitriadis E. Interleukin-11 and leukemia inhibitory factor regulate the adhesion of endometrial epithelial cells: implications infertility regulation.Endocrinol. (2009) 150:2915-23.

167. Paiva P, Salamonsen LA, Manuelpillaietal U. Interleukin11 promotes migration, but not proliferation, of human trophoblast cells, implying a role in placentation. Endocrinol. (2007) 148: 5566-72.

168. Cook IH, Evans J, Maldonado-Perez D, Critchley HO, Sales KJ, Jabbour HN. Prokineticin-1 (PROK1) modulates interleukin (IL)-11 expression via prokineticin receptor 1 (PROKR1) and the calcineurin/NFAT signalling pathway. Mol Hum Reprod . (2009) 16:158-69.

169. Menkhorst E, Salamonsen LA, Zhang J, Harrison CA, Gu J, Dimitriadis E. Interleukin 11 and activin A synergise to regulate progesterone-induced but not cAMP-induced Decidualization. J Reprod Immunol . (2010) 84:124-32.

170. Dimitriadis E, Stoikos C, Baca M, Fairlie WD, McCoubrie JE, Salamonsen LA. Relaxin and prostagland in E2 regulate interleukin 11 during human endometrial stromal cell Decidualization. J Clin Endocrinol Metabol . (2005) 90:3458-65.

171. Lucas ES, Vrljicak P, Muter J, Diniz-da-Costa MM, Brighton PJ, Kong CS, Lipecki J, Fishwick KJ, Odendaal J, Ewington LJ, Quenby S. Recurrent pregnancy loss is associated with a pro-senescent decidual response during the peri-implantation window. Commun Bio.(2020) 3:1-4.

172. Robb L, Li R, Hartley L, Nandurkar HH, Koentgen F, Begley CG. Infertility in female mice lacking the receptor for interleukin 11 is due to a defective uterine response to implantation. Nat Med.(1998) 4:303-8.

173. Bilinski P, Roopenian D, Gossler A. Maternal IL-11Ralpha function is required for normal decidua and feto-placental development in mice. Genes Dev.1998; 12:2234-43.

174. Alexander CM, Hansell EJ, Behrendtsen O et al. Expression and function of matrix metalloproteinases and their inhibitors at the materno+-embryonic boundary during mouse embryo implantation.Develop. (1996) 122:1723-36.

175. Behrendtsen O, Alexander CM, Werb Z. Metalloproteinases mediate extracellular matrix degradation 
by cells from mouse blastocyst outgrowths. Develop. ( 1992) 114:447-56.

176. Zourbas S, Dubanchet S, Martal J, Chaouat G. Localization of pro-inflammatory (IL-12, IL-15) and anti-inflammatory (IL-11, IL-13) cytokines at the foetomaternal interface during murine pregnancy. Clin Exper Immunol. (2001) 126:519-28.

177. Karpovich N, Klemmt P, Hwang JH, McVeigh JE, Heath JK, Barlow DH, Mardon HJ. The production of interleukin-11 and decidualization are compromised in endometrial stromal cells derived from patients with infertility. J Clin Endocrinol Metabol. (2005) 90: 1607-12.

178. Dimitriadis E, Robb L, Liu YX, Enders AC, Martin H, Stoikos C, Wallace E, Salamonsen LA. IL-11 and IL-11R $\alpha$ immunolocalisation at primate implantation sites supports a role for IL-11 in placentation and fetal development. Reprod Bio Endocrinol. (2003)1:34.

179. Chen HF, Lin CY, Chao KH, Wu MY, Yang YS, Ho HN. Defective production of interleukin-11 by decidua and chorionic villi in human anembryonic pregnancy. J Clin Endocrinol Metabol. (2002) 87: 2320-28.

180. Cha J, Sun X, Dey SK. Mechanisms of implantation: strategies for successful pregnancy. Nat Med. (2012) 18:1754-67.

181. Yeh CC, Chao KC, Huang SJ. Innate immunity, decidual cells, and preeclampsia. Reprod Sci. (2013) 20:339-53.

182. Miyazaki S, Tanebe K, Sakai M et al. Interleukin 2 receptor gamma chain $(\gamma \mathrm{c})$ knockout mice show less regularity in estrous cycle but achieve normal pregnancy without fetal compromise. Am J Reprod Immunol. (2002) 47: 222-30.

183. Dunn CL, Kelly RW, Critchley HO. Decidualization of the human endometrial stromal cell: an enigmatic transformation. Reprod Biomed Online. (2003) 7:151-61.

184. Kitaya K, Yasuda J, Yagi I et al. IL-15 expression at human endometrium and decidua. Bio Reprod. (2000) 63: 683-87.

185. Lessey BA, Young SL. Structure, function, and evaluation of the female reproductive tract. In Yen and Jaffe's Reprod . (2019): pp. 206-47.

186. Miravet-Valenciano J, Ruiz-Alonso M, Simón C. Transcriptomics of the Human Endometrium and Embryo Implantation. In Hum Reprod Pren Genet. (2019): pp. 271-91. Academic Press.

187. Lim KJ, Odukoya OA, Ajjan RA, Li TC, Weetman AP, Cooke ID. The role of T-helper cytokines in human reproduction. Fertil Steril. (2000) 73:136-42.

188. King K, Smith S, Chapman M, Sacks G. Detailed analysis of peripheral blood natural killer (NK) cells in women with recurrent miscarriage.Hum Reprod. (2010) 251:52-8.

189. Hutter S, Heublein S, Knabl J, Andergassen U, Vrekoussis T, Makrigiannakis A, et al. Macrophages: are they involved in endometriosis, abortion and preeclampsia and how? J Nippon Med Sch . (2013) 802:97-103. 10.1272/jnms.80.97

190. Guenther S, Vrekoussis T, Heublein S, Bayer B, Anz D, Knabl J, et al. Decidual macrophages are significantly increased in spontaneous miscarriages and over-express FasL: a potential role for macrophages in trophoblast apoptosis. Int J Mol Sci. (2012) 137:9069-80.

191. Bao SH, Wang XP, De Lin Q, Wang WJ, Yin GJ, Qiu LH. Decidual CD4+CD25+CD127dim/- regulatory $\mathrm{T}$ cells in patients with unexplained recurrent spontaneous miscarriage. Eur J Obstet Gynecol Reprod Biol. (2011) 1551:94-8.

192. Osborne LM, Brar A, Klein SL. The role of Th17 cells in the pathophysiology of pregnancy and perinatal mood and anxiety disorders.Brain Behav Immun. (2019) 76:7-16.

193. Qian J, Zhang N, Lin J, Wang C, Pan X, Chen L, Li D, Wang L. Distinct Pattern of Th17/Treg Cells in Pregnant Women with a History of Unexplained Recurrent Spontaneous Abortion. Biosci Tren. (2018) 12: 157-67.

194. Saifi B, Rezaee SA, Tajik N, Ahmadpour ME, Ashrafi M, Vakili R, SoleimaniAsl S, Aflatoonian R, Mehdizadeh M. Th17 Cells and Related Cytokines in Unexplained Recurrent Spontaneous Miscarriage at the Implantation Window. Reprod Biomed Online. (2014) 29: 481-9

195. Zhang XX, Kang XM, Zhao AM. Regulation of CD4+FOXP3+T Cells by CCL20/CCR6 Axis in Early Unexplained Recurrent Miscarriage Patients. Genet Mol Res. (2015) 14: 9145-54. 
196. Wu M, Liu P, Cheng L. Galectin-1 Reduction and Changes in T Regulatory Cells May Play Crucial Roles in Patients with Unexplained Recurrent Spontaneous Abortion. Int J Clin Exp Pathol. (2015) 8: 1973-8.

197. Inada K, Shima T, Ito M, Ushijima A, Saito S. Helios-Positive Functional Regulatory T Cells are Decreased in Decidua of Miscarriage Cases with Normal Fetal Chromosomal Content. J Reprod Immunol.(2015) 107: 10-19.

198. Qian ZD, Huang LL, Zhu XM. An immunohistochemical study of CD83- and CD1a-positive dendritic cells in the decidua of women with recurrent spontaneous abortion. Eur J Med Res . (2015) 20:2.

199. Askelund K, Liddell HS, Zanderigo AM, Fernando NS, Khong TY, Stone PR, Chamley LW. CD83(+)Dendritic Cells in the Decidua of Women with Recurrent Miscarriage and Normal Pregnancy. Placenta . (2004) 25: 140-5

200. Tirado-Gonzalez I, Munoz-Fernandez R, Blanco O, Leno-Duran E, Abadia-Molina AC, Olivares EG. Reduced proportion of decidual DC-SIGN+ cells in human spontaneous abortion. Placenta. (2010) 31:1019-22.

201. Giuliani E, Parkin KL, Lessey BA, Young SL, Fazleabas AT. Characterization of Uterine NK Cells in Women with Infertility or Recurrent Pregnancy Loss and Associated Endometriosis. Am J Reprod Immunol . (2014) 72: 262-69

202. Clifford K, Flanagan AM, Regan L. Endometrial CD56+Natural Killer Cells in Women with Recurrent Miscarriage: A Histomorphometric Study.Hum Reprod. (1999) 14: 2727-30.

203. Tuckerman E, Laird SM, Prakash A, Li TC. Prognostic Value of the Measurement of Uterine Natural Killer Cells in the Endometrium of Women with Recurrent Miscarriage. Hum Reprod. (2007) 22: 220813.

204. Kuon RJ, Weber M, Heger J, Santillan I, Vomstein K, Bar C, Strowitzki T, Markert UR, Toth B. Uterine Natural Killer Cells in Patients with Idiopathic Recurrent Miscarriage. Am J Reprod Immunol. (2017) 78: e12721.

205. El-Azzamy H, Dambaeva SV, Katukurundage D, Salazar Garcia MD, Skariah A, Hussein Y, Germain A, Fernandez E, Gilman-Sachs A, Beaman KD, et al. Dysregulated Uterine Natural Killer Cells and Vascular Remodeling in Women with Recurrent Pregnancy Losses. Am J Reprod Immunol.(2018) 80: e13024.

206. Seshadri S, Sunkara SK. Natural Killer Cells in Female Infertility and Recurrent Miscarriage: A Systematic Review and Meta-Analysis.Hum Reprod Update . (2014) 20: 429-38.

207. Kuon RJ, Vomstein K, Weber M, Muller F, Seitz C, Wallwiener S, Strowitzki T, Schleussner E, Markert UR, Daniel V, et al. The "Killer Cell Story" in Recurrent Miscarriage: Association Between Activated Peripheral Lymphocytes and Uterine Natural Killer Cells. J Reprod Immunol. (2017) 119: 9-14.

208. Fuchinoue K, Fukui A, Chiba H, Kamoi M, Funamizu A, Taima A, Fukuhara R, Mizunuma H. Expression of Retinoid-Related Orphan Receptor (ROR) rt on NK22 Cells in the Peripheral Blood and Uterine Endometrium of Women with Unexplained Recurrent Pregnancy Loss and Unexplained Infertility. $J$ Obstet Gynaecol Res . (2016) 42: 1541-52

209. Kwak-Kim J, Yang KM, Gilman-Sachs A. Recurrent Pregnancy Loss: A Disease of Inflammation and Coagulation. J Obstet Gynaecol Res.(2009) 35: 609-22.

210. O'Hern Perfetto C, Fan X, Dahl S, Krieg S, Westphal LM, Bunker Lathi R, Nayak NR. Expression of Interleukin-22 in Decidua of Patients with Early pregnancy and Unexplained Recurrent Pregnancy Loss. J Assist Reprod Genet. (2015) 32: 977-84.

211. Schumacher A, Ehrentraut S, Scharm M, Wang H, Hartig R, Morse HC III, et al. Plasma cell alloantigen 1 and IL-10 secretion define two distinct peritoneal B1a B cell subsets with opposite functions, $\mathrm{PC} 1$ (high) cells being protective and $\mathrm{PC1}$ (low) cells harmful for the growing fetus. Front Immunol. (2018) 9:1045. doi: 10.3389/fimmu.2018.01045

212. AlJameil N, Tabassum H, AlMayouf H, Alshenefy A, Almohizea MM, Ali MN. Identification of serum cytokines as markers in women with recurrent pregnancy loss or miscarriage using milliplex analysis. (2018).

213. Wilczyński JR, Radwan P, Tchórzewski H, Banasik M. Immunotherapy of patients with recurrent 
spontaneous miscarriage and idiopathic infertility: does the immunization-dependent Th2 cytokine overbalance really matter?. Arch Immunol Ther Exper. (2012) 60(2):151-60.

214. Ismail AM, Agban MN, Hasanein AS, Rayan AA, Abbas AM. Role of Th-1 cell cytokines, leukemia inhibitory factor and hoxA genes in women with recurrent pregnancy loss. Mid East Fertil Soc J. (2017) 22:300-4.

215. Xu L, Qiu T, Wang Y, Chen Y, Cheng W. Expression of C-type lectin receptors and Toll-like receptors in decidua of patients with unexplained recurrent spontaneous abortion. Reprod Fertil Develop (2017) 29:1613-24.

216. Comba C, Bastu E, Dural O, Yasa C, Keskin G, Ozsurmeli M, Buyru F, Serdaroglu H. Role of Inflammatory Mediators in Patients with Recurrent Pregnancy Loss. Fertil Steril. (2015) 104: 1467-74

217. Jasper MJ, Tremellen KP, Robertson SA. Reduced Expression of IL-6 and IL-1alpha mRNAs in Secretory Phase Endometrium of Women with Recurrent Miscarriage. J Reprod Immunol. (2007) 73: 74-84.

218. Von Wolff M, Thaler CJ, Strowitzki T, Broome J, Stolz W, Tabibzadeh S. Regulated Expression of Cytokines in Human Endometrium Throughout the Menstrual Cycle: Dysregulation in Habitual Abortion. Mol Hum Reprod. (2000) 6:627-34

219. Krieg SA, Fan X, Hong Y, Sang QX, Giaccia A, Westphal LM, Lathi RB, Krieg AJ, Nayak NR. Global Alteration in Gene Expression Profiles of Deciduas from Women with Idiopathic Recurrent Pregnancy Loss. Mol Hum Reprod. (2012) 189: 442-50.

220. Gao Y, Wang P, Zou T, Zhang Z, Liang W. Increased Th17 and reduced Treg cells in patients with unexplained recurrent spontaneous abortion. Clin Experim Obstet Gynecol. (2019) 46:458-60.

221. Monastero RN, Pentyala S. Cytokines as biomarkers and their respective clinical cutoff levels. Int $J$ Inflammat. (2017) 2017.

222. Liang PY, Diao LH, Huang CY, Lian RC, Chen X, Li GG, Zhao J, Li YY, He XB, Zeng Y. The pro-inflammatory and anti-inflammatory cytokine profile in peripheral blood of women with recurrent implantation failure. Reprod Bomed online. (2015) 31:823-6.

223. Salama KM, Alloush MK. Are the cytokines TNF alpha and IL 1Beta early predictors of embryo implantation? Cross sectional study. J Reprod Immunol. (2020) 137:102618

224. Alijotas-Reig J, Esteve-Valverde E, Ferrer-Oliveras R, Llurba E, Gris JM. Tumor necrosis factor-alpha and pregnancy: focus on biologics. An updated and comprehensive review. Clin Rev Allergy Immunol . (2017) 53:40-53.

225. Ruiz-Alonso M, Blesa D, Simon C. The genomics of the human endometrium. Biochim Biophys Acta. (2012) 1822:1931-42.

226. Mor G, Aldo P, Alvero AB. The unique immunological and microbial aspects of pregnancy. Nat Rev Immunol. (2017)17:469-82.

227. Kosova G, Stephenson MD, Lynch VJ, Ober C. Evolutionary forward genomics reveals novel insights into the genes and pathways dysregulated in recurrent early pregnancy loss. Hum Reprod.(2015) 30:51929.

228. Beydoun H, Saftlas AF. Association of human leucocyte antigen sharing with recurrent spontaneous abortions. Tiss Antig. (2005) 65:123-35.

229. Chau A, Markley JC, Juang J, Tsen LC. Cytokines in the perinatal period-Part I. Int J Obstet Anesth. (2016) 26: 39-47.

230. Cartwright JE, Fraser R, Leslie K, Wallace AE, James JL. Remodelling at the maternal-fetal interface: relevance to human pregnancy disorders. Reprod. (2010) 140:803-13.

231. Lyzikova YA, Zinovkin DA, Pranjol MZ. Increase in FoxP3, CD56 immune cells and decrease in glands PGRMC1 expression in the endometrium are associated with recurrent miscarriages. Europ $J$ Obstet Gynecol Reprod Biol. (2020) 245:121-6.

232. Tabibzadeh S, Sun XZ. Cytokine expression in human endometrium throughout the menstrual cycle. Hum Reprod. (1992) 7:1214-21.

233. Linjawi S, Li TC, Tuckerman EM, Blakemore AI, Laird SM. Expression of interleukin-11 receptor $\alpha$ and interleukin-11 protein in the endometrium of normal fertile women and women with recurrent 
miscarriage. J Reprod Immunol. (2004) 64:145-55.

234. Yui J, Garcia-Lloret M, Wegmann TG, Guilbert LJ. Cytotoxicity of tumour necrosis factor-alpha and gamma-interferon against primary human placental trophoblasts. Placent. (1994) 15:819-35.

235. Haddad EK, Duclos AJ, Antecka E, Lapp WS, Baines MG. Role of interferon-gamma in the priming of decidual macrophages for nitric oxide production and early pregnancy loss. Cell Immunol. (1997) 181:68-75.

236. Knofler M, Mosl B, Bauer S, Griesinger G, Husslein P.TNF-alpha/TNFRI in primary and immortalized first trimester cytotrophoblasts.Placent. (2000) 21:525-35.

237. Jokhi PP, King A, Boocock C, Loke YW. Secretion of colony stimulating factor-1 by human first trimester placental and decidual cell populations and the effect of this cytokine on trophoblast thymidine uptake invitro. Hum Reprod . (1995) 10:2800-7.

238. Hamilton GS, Lysiak JJ, Watson AJ, Lala PK. Effects of colony stimulating factor-1 on human extravillous trophoblast growth and invasion. J Endocrinol. (1998) 159: 69-77.

239. Stewart CL, Kaspar P, Brunet LJ, Bhatt H, Gadi I, Köntgen F, Abbondanzo SJ. Blastocyst implantation depends on maternal expression of leukaemia inhibitory factor. Nat. (1992) 359:76.

240. Piccinni MP. T cells in normal pregnancy and recurrent pregnancy loss. Reprod BioMed Online. (2006) 13:840-4.

241. Bennett WA, Lagoo-Deenadayalan S, Whitworth NS, Stopple JA, Barber, WH, Hale E, et al. First trimester human, inflammatory cvebia, the carfiir, cytokine network of pregnancy. Am J Reprod Immunol . (1999) 41:70-78.

242. Bennett W, Lagoo-Deenadayalan S, Whitworth N, Brackin M, Hale E, Cowan B. Expression and production of interleukin-10 by human trophoblast: relationship to pregnancy immunotolerance. Biol Med: Official J Societ Invest Early Pregn. (1997) 3:190-8.

243. Hakimi H, Zare-Bidaki M, Zainodini N, Assar S, Arababadi MK. Significant roles played by IL-10 in chlamydia infections.Inflammat. (2014) 37: 818-23.

244. Robertson SA, Skinner RJ, Care AS. Essential role for IL-10 in resistance to lipopolysaccharide-induced preterm labor in mice.J Immunol. (2006) 177:4888-96.

245. Zhang A, Fu J, Ning B, Li D, Sun N, Wei W, et al. Tolerogenic dendritic cells generated with IL10/TGFß1 relieve immune thrombocytopenia in mice. Thromb Res. (2013) 132 :63-68.

246. Teng CB, Diao HL, Ma H, Cong J, Yu H, Ma XH, et al. Signal transducer and activator of transcription 3 (Stat3) expression and activation in rat uterus during early pregnancy. Reprod. (2004) 128:197-205.

247. Ladyman SR, Grattan DR. Region-specific reduction in leptin-induced phosphorylation of signal transducer and activator of transcription-3 (STAT3) in the rat hypothalamus is associated with leptin resistance during pregnancy. Endocrinol. (2004) 145: 3704-11.

248. Hutchins AP, Diez D, Miranda-Saavedra D. The IL-10/STAT3-mediated anti-inflammatory response: recent developments and future challenges.Brief Funct Genom. (2013) 12 :489-98.

249. Liu B, Wu H, Huang Q, Li M, Fu X. Phosphorylated STAT3 inhibited the proliferation and suppression of decidual Treg cells in unexplained recurrent spontaneous abortion. Int Immunopharmacol. (2020) 82:106337.

250. Thaxton JE, Sharma S. Interleukin-10: a multi-faceted agent of pregnancy. Am J Reprod Immunol. (2010) 63:482-91.

251. Chaouat G, Meliani AA, Martal J, Raghupathy R, Elliott JF, Elliot J, Mosmann T, Wegmann TG. IL-10 prevents naturally occurring fetal loss in the CBA x DBA/2 mating combination, and local defect in IL-10 production in this abortion-prone combination is corrected by in vivo injection of IFN-tau. $J$ Immunol. (1995) $154: 4261-8$.

252. Tabibzadeh S. Ubiquitous expression of $\mathrm{TNF} \alpha /$ cachectin in human endometrium. Am J Reprod Immunol. ( 1991) 26:1-4.

253. Hunt JS, Chen HL, Hu XL, Tabibzadeh S. Tumor necrosis factor-alpha messenger ribonucleic acid and protein in human endometrium. Hum Reprod. (1992) 47: 141-7.

254. Philippeaux MM, Piguet PF. Expression of tumour necrosis factor-alpha and its mRNA in the endometrial mucosa during the menstrual cycle.Am J Pathol. (1993) 143:480-6. 
255. Haimovici F, Hill JA, Anderson DJ. The effects of soluble products of activated lymphocytes and macrophages on blastocyts implantation events in vitro. Biol Reprod. (1991) 44:69-75.

256. Suffys P, Beyaert R, Van RF, Fiers W. TNF in combination with interferon-gamma is cytotoxic to normal, untransformed mouse and rat embryo fibroblast-like cells. Antican Res. (1989) 9:167-71.

257. Mueller-Eckhardt G, Mallmann P, Neppert J, Lattermann A, Melk A, Heine O, Pfeiffer R, Zingsem J, Domke N, Mohr-Pennert A. Immunogenetic and serological investigations in nonpregnant and in pregnant women with a history of recurrent spontaneous abortions. J Reprod Immunol . (1994) 27: 95-109.

258. Jenkins C, Roberts J, Wilson R, Mac Lean MA, Shilito J, Walker JJ. Evidence of a TH1 type response associated with recurrent miscarriage. Fertil Steril. (2000) 6:1206-8.

259. Trincheiri G. Interleukin-12 and its role in the generation of Th-1 cells. Immunol Today. (1993) 14:335-8.

260. Hill JA, Polgar K, Anderson DJ. T-helper1-type immunity totrophoblast in women with recurrent spontaneous abortion. JAMA. (1995) 273:1933-6.

261. Michimata T, Tsuda H, Sakai M, Fujimura M, Nagata K, Nakamura M, Saito S. Accumulation of CRTH2-positive T-helper 2 and T-cytotoxic 2 cells at implantation sites of human decidua in a prostaglandin D2-mediated manner. Mol Hum Reprod. (2002) 8: 181-7.

262. Michimata T, Sakai M, Miyazaki S, Ogasawara MS, Suzumori K, Aoki K, Nagata K, Saito S. Decrease of T-helper 2 and T-cytotoxic 2 cells at implantation sites occurs in unexplained recurrent spontaneous abortion with normal chromosomal content. Hum Reprod . (2003) 18:1523-8.

263. Krishnan L, Guilbert LJ, Wegmann TG, Belosevic M, Mosmann TR.T helper 1 response against Leishmania major in pregnant C57BL/6 mice increases implantation failure and fetal resorptions. Correlation with increased IFN-gamma and TNF and reduced IL-10 production by placental cells. $J$ Immunol. (1996) 156:653-62.

264. Daher S, Fonseca F, Ribeiro OG, Musatti CC, Gerbase-DeLima M. Tumor necrosis factor during pregnancy and the onset of labor and spontaneous abortion. Eur $J$ Obstet Gynecol Reprod Biol. (1999) 83:77-9.

265. Hehlgans T, Pfeffer K. The intriguing biology of the tumour necrosis factor/tumour necrosis factor receptor superfamily: players, rules and the games. Immunol . (2005) 115:1-20.

266. Kwak-Kim JY, Gilman-Sachs A, Kim CE. T helper 1 and 2 immune responses in relationship to pregnancy, nonpregnancy, recurrent spontaneous abortions and infertility of repeated implantation failures. Chem Immunol Aller. (2005) 88:64-79.

267. Garcia-Lloret MI, Winkler-Lowen B, Guilbert LJ. Monocytes adhering by LFA-1 to placental syncytiotrophoblasts induce local apoptosis via release of TNF- $\alpha$. A model for hematogenous initiation of placental inflammations. J Leukocyt Biol. (2000) 68:903-8.

268. Fortunato SJ, Menon R, Lombardi SJ. Support for an infection induced apoptotic pathway in human fetal membranes. Am J Obstet Gynecol. (2001) 184:1392-8.

269. Raghupathy R, Makhseed M, Azizieh F, Omu A, Gupta M, Farhat R. Cytokine production by maternal lymphocytes during normal human pregnancy and in unexplained recurrent spontaneous abortion. Hum Reprod. (2000) 15:713-8.

270. Kinsky R, Delage G, Rosin N, Thang MN, Hoffmann M, Chaouat G.A murine model of NK cell mediated resorption. Am J Reprod Immunol.(1990) 23:73-7.

271. Paganin C, Matteucci C, Cenzuales S, Mantovani A, Allavena P. IL-4inhibits binding and cytotoxicity of NK cells to vascular endothelium. Cytokine. (1994) 6:135-40.

272. Loza MJ, Peters SP, Zangrilli JG, Perussia B. Distinction between IL-13+ and IFN- $\gamma+$ natural killer cells and regulation of their pool size by IL-4. Eur J Immunol. (2002) 32:413-23.

273. Seo N, Tokura Y, Furukawa F, Takigawa M. Down-regulation of tumoricidal NK and NK T cell activities by MHC Kb molecules expressed on Th2-type $\gamma \delta \mathrm{T}$ and $\alpha \beta \mathrm{T}$ cells coinfiltrating in early B16 melanoma lesions. J Immunol. (1998) 161:4138-45.

274. Deniz G, Akdis M, Aktas E, Blaser K, Akdis CA. Human NK1 and NK2 subsets determined by purification of IFN- $\gamma$-secreting and IFN- $\gamma$-nonsecreting NK cells. Eur J Immunol. ( 2002) 32:879-84. 
275. Smith SD, Dunk CE, Aplin JD, Harris LK, Jones RL. Evidence for Immune Cell Involvement in Decidual Spiral Arteriole Remodeling in Early Human Pregnancy. Am J Pathol. (2009) 174: 1959-71

276. Zhang J, Chen Z, Smith GN, Croy BA. Natural Killer Cell-Triggered Vascular Transformation: Maternal Care Before Birth? Cell Mol Immunol. (2011) 8: 1-11

277. Helige C, Ahammer H, Moser G, Hammer A, Dohr G, Huppertz B, Sedlmayr P. Distribution of Decidual Natural Killer Cells and Macrophages in the Neighbourhood of the Trophoblast Invasion Front: A Quantitative Evaluation. Hum Reprod. (2014) 29: 8-17.

278. Koopman LA, Kopcow HD, Rybalov B, Boyson JE, Orange JS, Schatz F, Masch R, Lockwood CJ, Schachter AD, Park PJ, et al. Human Decidual Natural Killer Cells are a Unique NK Cell Subset with Immunomodulatory Potential. J Exp Med . (2003) 198: 1201-12.

279. Liu S, Diao L, Huang C, Li Y, Zeng Y, Kwak-Kim JYH. The Role of Decidual Immune Cells on Human Pregnancy. J Reprod Immunol.(2017) 124:44-53.

280. Moffett A, Chazara O, Colucci F. Maternal Allo-Recognition of the Fetus. Fertil Steril. (2017) 107: 1269-72.

281. Kennedy PR, Chazara O, Gardner L, Ivarsson MA, Farrell LE, Xiong S, Hiby SE, Colucci F, Sharkey AM, Moffett, A. Activating KIR2DS4 Is Expressed by Uterine NK Cells and Contributes to Successful Pregnancy.J Immunol. (2016) 197: 4292-4300

282. Sharkey AM, Xiong S, Kennedy PR, Gardner L, Farrell LE, Chazara O, Ivarsson MA, Hiby SE, Colucci F, Moffett A. Tissue-Specific Education of Decidual NK Cells. J Immunol. (2015) 195: 3026-32.

283. Moffett A. NK Cell Allorecognition. Nat Rev Immunol. (2017) 17:466.

284. Penman BS, Moffett A, Chazara O, Gupta S, Parham P. Reproduction, Infection and Killer-Cell Immunoglobulin-Like Receptor Haplotype Evolution. Immunogenet. (2016) 68: 755-64

285. Brighton PJ, Maruyama Y, Fishwick K, Vrljicak P, Tewary S, Fujihara R, Muter J, Lucas ES, Yamada T, Woods L, Lucciola R. Clearance of senescent decidual cells by uterine natural killer cells in cycling human endometrium. Elife. (2017) 6:e31274.

286. Somigliana E, Vigano P, Vignali M. Endometriosis and unexplained recurrent spontaneous abortion: pathological states resulting from aberrant modulation of natural killer function? Hum Reprod Update . (1999) 5:40-51.

287. Kim SG, Paek MY, Ko IG. Peripheral blood level of natural killer cells in pregnant women with recurrent spontaneous abortion during the 6-12 weeks gestation. Arch Med Heal Sc. (2019) 7:191.

288. Zhang YN, Huang CY, Lian RC, Xu J, Fu YF, Zeng Y, Tu WW. Relationship between the cytotoxic activity of peripheral blood natural killer cells and recurrent miscarriage. (2020).

289. Sokolov DI, Mikhailova VA, Agnayeva AO, Bazhenov DO, Khokhlova EV, Bespalova ON, Gzgzyan AM, Selkov SA. NK and trophoblast cells interaction: cytotoxic activity on recurrent pregnancy loss. Gynecol Endocrinol. (2019) 35(sup1):5-10.

290. Chaouat G. Regulation of T-cell activities at the feto-placental interface by placenta? Am J Reprod Immunol. (1999) 42:199-204.

291. Dealtry GB, Clark DE, Sharkey A, Charnock-Jones DS, Smith SK. VII international congress of reproductive immunology. New Delhi, 27-30 October 1998: expression and localization of the Th2type cytokine interleukin-13 and its receptor in the placenta during human pregnancy. Am J Reprod Immunol. (1998) 40:283-90.

292. Roth I, Corry DB, Locksley RM, Abrams JS, Litton MJ, Fisher SJ. Human placental cytotrophoblasts produce the immunosuppressive cytokine interleukin 10. J Exper Med . (1996)184:539-48.

293. Jones CA, Finlay-Jones JJ, Hart PH. Type-1 and type-2 cytokines in human late-gestation decidual tissue. Bio Reprod. (1997) 57:303-11.

294. Bennett WA, Lagoo-Deenadayalan S, Brackin MN, Hale E, Cowan BD. Cytokine expression by models of human trophoblast as assessed by a semiquantitative reverse transcription-polymerase chain reaction technique. Am J Reprod Immunol .(1996) 36:285-94.

295. Lim KJ, Odukoya OA, Ajjan RA, Li TC, Weetman AP, Cooke ID. Profile of cytokine mRNA expression in peri-implantation human endometrium. Mol Hum Reprod. (1998) 4:77-81.

296. Saito S. Cytokine network at the feto-maternal interface. J Reprod Immunol. (2000) 47:87-103. 
297. Vives A, Balasch J, Yague J, Quinto L, Ordi J, Vanrell JA. Type-1 and type-2 cytokines in human decidual tissue and trophoblasts from normal and abnormal pregnancies detected by reverse transcriptase polymerase chain reaction (RT-PCR). Am J Reprod Immunol. (1999) 42:361-8.

298. Lea RG, Tulppala M, Critchley HO. Deficient syncytiotrophoblast tumour necrosis factor-alpha characterizes failing first trimester pregnancies in a sub-group of recurrent miscarriage patients. Hum Reprod.(1997) 12:1313-20.

299. Ledee-Bataille N, Dubanchet S, Coulomb-Lhermine A, Durand-Gasselin I,Frydman R, Chaouat G. A new role for natural killer cells, interleukin (IL)-12 and IL-18 in repeated implantation failure after invitro fertilization. Fertil Steril. (2004) 81:59-65.

300. Jasper MJ, Tremellen KP, Robertson SA. Primary unexplained infertility is associated with reduced expression of the T-regulatory cell transcription factor Foxp3 in endometrial tissue. Mol Hum Reprod. (2006) 12:301-8.

301. Hu X, Wang Y, Mor G, Liao A. Forkhead box P3 is selectively expressed in human trophoblasts and decreased in recurrent pregnancy loss.Placenta. (2019) 81:1-8.

302. Sakaguchi S. Naturally arising Foxp3-expressing CD25+CD4+ regulatory T cells in immunological tolerance to self and non-self. Nat Immunol. (2005) 6:345-52.

303. Akbar AN, Vukmanovic-Stejic M, Taams LS, Macallan DC. The dynamic co-evolution of memory and regulatory CD4+ T cells in the periphery.Nat Rev Immunol. (2007) 7:231-7.

304. Shevach EM. Mechanisms of Foxp3+ T regulatory cell mediated suppression. Immunity. (2009) 30:636-45.

305. Salker MS, Nautiyal J, Steel JH, Webster Z, Šućurović S, Nicou M, Singh Y, Lucas ES, Murakami K, Chan YW, James S. Disordered IL-33/ST2 activation in decidualizing stromal cells prolongs uterine receptivity in women with recurrent pregnancy loss. PLoSone. (2012) 7:1-18.

306. Salker M, Teklenburg G, Molokhia M, Lavery S, Trew G, Aojanepong T, Mardon HJ, Lokugamage AU, Rai R, Landles C, Roelen BA. Natural selection of human embryos: impaired decidualization of endometrium disables embryo-maternal interactions and causes recurrent pregnancy loss. PloS one . (2010) 5:1-7.

307. Tan SY, Hang F, Purvarshi G, Li MQ, Meng DH, Huang LL. Decreased endometrial vascularity and receptivity in unexplained recurrent miscarriage patients during midluteal and early pregnancy phases. Taiw J Obstet Gynecol. (2015) 54:522-6.

308. Lockwood CJ, Huang SJ, Chen CP, Huang Y, Xu J, Faramarzi S, Kayisli O, Kayisli U, Koopman L, Smedts D, Buchwalder LF. Decidual Cell Regulation of Natural Killer Cell-Recruiting Chemokines: Implications for the Pathogenesis and Prediction of Preeclampsia. Am J Pathol. (2013) 183:841-56.

309. Li A, Dubey S, Varney ML, Dave BJ, Singh RK. IL-8 directly enhanced endothelial cell survival, proliferation, and matrix metalloproteinases production and regulated angiogenesis. J Immunol. (2003) 170:3369-76.

310. Tsuda S, Nakashima A, Shima T, Saito S. New paradigm in the role of regulatory T cells during pregnancy. Front Immunol. (2019) 10:573.

311. Schjenken JE, Moldenhauer LM, Zhang B, Care AS, Groome HM, Chan HY, Hope CM, Barry SC, Robertson SA. MicroRNA miR-155 is required for expansion of regulatory T cells to mediate robust pregnancy tolerance in mice. Mucosal Immunol. (2020):1-7.

Figure Legends

Fig 1 The different types of decidua (decidua parietalis, capsularis and basalis) and the intimate association between the developing embryo and the placental tissue. Decidua basalis develops from the endometrium that immediately lies under the site of implantation while as decidua capsularis originate from the thin endometrial stroma rim that covers the blastocyst. The endometrium that lines remaining part of uterine cavity forms decidua parietalis. Decidua provides nutrition to the growing embryo before the formation of placenta and more importantly plays a key role in shielding embryo from the maternal immune cell attack

Fig 2 Micrographic representation of stromal decidual cells. These cells are large polygonal with nuclei that stain pale and possess eosinophilic granular cytoplasm 
Fig 3 A preparatory pathway for embryo implantation and pregnancy. Decidualization that begins during the menstrual cycle (midsecretory phase) in response to increased estrogen and progesterone levels involves the transformation of endometrial stromal cells into decidual cells in inflammatory and anti-inflammatory milieu via retinoid and corticosteroid signaling pathway reprogramming as well as regulates the specific uNK cells (CD56 bright and CD16 dim) that in turn control inflammation, angiogenesis and vascular remodeling via IL15 and IL11. The inflammatory responses synchronize the implantation window. IL11 is stimulated by relaxin and PGE2 via cAMP/PKA signaling pathway whereas prokineticin-1 triggers it via calcineurin-NFAT signaling pathway and this cytokine is linked with decidualization, implantation and placentation.

Table 1 Overview of cytokines with their nature and cellular source

\begin{tabular}{|c|c|c|c|}
\hline Signature cytokine & Cytokine type & Cell type & References \\
\hline $\mathrm{IFN \gamma}$ & Inflammatory & Th1 & {$[12]$} \\
\hline IL4, IL5, IL9, IL13 & Anti-inflammatory & Th2 & {$[12]$} \\
\hline IL17 & Pro-inflammatory & Th17 & {$[12]$} \\
\hline TGF $\beta$, IL10 & Anti-inflammatory & Tregs & {$[14]$} \\
\hline IL35 & Immunosuppressive & Trophoblasts & {$[15]$} \\
\hline TNF $\alpha$, IL1 $\beta$ & Pro-inflammatory & $\begin{array}{l}\text { Endometrial stromal } \\
\text { cell }\end{array}$ & {$[16]$} \\
\hline IL6, IL10 & Anti-inflammatory & $\begin{array}{l}\text { Decidual stromal cells/ } \\
\text { Endometrial stromal } \\
\text { cell }\end{array}$ & {$[17]$} \\
\hline IL6, IL7 & Anti-inflammatory & $\begin{array}{l}\text { Endo-cervical epithelial } \\
\text { cells }\end{array}$ & {$[18,19]$} \\
\hline $\begin{array}{l}\text { TGF } \beta \text {, TNF } \alpha, \text { IL6, IL8, } \\
\text { G-CSF (Granulocyte } \\
\text { colony stimulating factor) }\end{array}$ & Pro-/anti-inflammatory & Uterine epithelial cells & {$[20,21]$} \\
\hline $\begin{array}{l}\text { Type } 1 \text { (IFN } \gamma, \text { IL2, } \\
\text { TNF } \alpha \text { )and Type } 2 \\
\text { (IL4, IL5,IL9, } \\
\text { IL10,IL13) }\end{array}$ & Pro-/anti-inflammatory & $\begin{array}{l}\text { Maternal T } \\
\text { lymphocytes }\end{array}$ & {$[22,23,24,25]$} \\
\hline IL10, TGF $\beta$ & Anti-inflammatory & Decidual macrophages & {$[26,27]$} \\
\hline $\begin{array}{l}\text { IL1 } \beta, \text { IL4, IL6, IL8, } \\
\text { IL10, IL13, IFN } \gamma \text {, } \\
\text { TNF } \alpha\end{array}$ & Pro-/anti-inflammatory & $\begin{array}{l}\text { Uterine natural killer } \\
\text { cells }\end{array}$ & {$[28]$} \\
\hline
\end{tabular}

Table 2 Overview of changes in the immune cells and their role during reproductive cycle and early pregnancy

\begin{tabular}{llll}
\hline Cells & Changes & Functions & References \\
\hline T lymphocytes & Decreased/unaffected & Defensive or & {$[29,30,31,32]$} \\
& from follicular to luteal & destructive for the & \\
phase & developing embryo & \\
& depending on \\
& particular subset of & \\
& cells &
\end{tabular}




\begin{tabular}{|c|c|c|c|}
\hline Cells & Changes & Functions & References \\
\hline $\begin{array}{l}\text { T helper cells (Th1, Th2, } \\
\text { Th17) }\end{array}$ & $\begin{array}{l}\text { Lower levels during } \\
\text { mid-luteal and late luteal } \\
\text { phase as compared to } \\
\text { early follicular phase. }\end{array}$ & $\begin{array}{l}\text { Th1 cells manufacture } \\
\text { pro-inflammatory } \\
\text { cytokines Th2 cells } \\
\text { cytokines with } \\
\text { anti-inflammatory effects } \\
\text { Th17 cells also produce } \\
\text { pro-inflammatory type of } \\
\text { cytokines }\end{array}$ & {$[33]$} \\
\hline B lymphocytes & $\begin{array}{l}\text { Slightly increased } \\
\text { toward the end of } \\
\text { luteal phase }\end{array}$ & $\begin{array}{l}\text { Still uncertain, possibly } \\
\text { involved in early stage } \\
\text { of pregnancy }\end{array}$ & {$[34,35,31]$} \\
\hline $\begin{array}{l}\text { Uterine dendritic cells } \\
\text { (uDCs) }\end{array}$ & $\begin{array}{l}\text { Controversially } \\
\text { immature DCs show an } \\
\text { increasing trend from } \\
\text { follicular to luteal } \\
\text { phase and reach to } \\
\text { peak level during } \\
\text { menstrual phase. } \\
\text { However, mature DCs } \\
\text { remain unchanged } \\
\text { during reproductive } \\
\text { cycle }\end{array}$ & $\begin{array}{l}\text { Implicated embryo } \\
\text { acceptance, remodeling } \\
\text { of uterus, angiogenesis, } \\
\text { invasion and } \\
\text { differentiation of } \\
\text { trophoblasts, decide } \\
\text { the differentiation of } \\
\text { progenitors of T cells } \\
\text { into Tregs as well as } \\
\text { the activation and } \\
\text { proliferation of Tregs }\end{array}$ & {$[30,36,37-42]$} \\
\hline $\begin{array}{l}\text { Uterine natural killer } \\
(\mathrm{uNK}) \text { cells }\end{array}$ & $\begin{array}{l}\text { Show gradual rise from } \\
\text { follicular to luteal } \\
\text { phase and reaches } \\
\text { maximum level in end } \\
\text { of luteal phase and } \\
\text { decidua of pregnancy }\end{array}$ & $\begin{array}{l}\text { Remodeling of spiral } \\
\text { arteries, regulation of } \\
\text { invasion of } \\
\text { trophoblasts, } \\
\text { angiogenesis } \\
\text { enhancement }\end{array}$ & {$[9,29,30,34,43-46]$} \\
\hline Treg cells & $\begin{array}{l}\text { Proliferate in } \\
\text { pre-implantation } \\
\text { endometrium, } \\
\text { increased at decidual } \\
\text { site for implantation } \\
\text { and during early period } \\
\text { of pregnancy until } \\
\text { mid-gestation }\end{array}$ & $\begin{array}{l}\text { Treg cells are crucial } \\
\text { for regulating extreme } \\
\text { maternal inflammatory } \\
\text { reaction at the site of } \\
\text { implantation, } \\
\text { participate in } \\
\text { materno-immune } \\
\text { tolerance to embryonic } \\
\text { allograft mainly during } \\
\text { early stage of } \\
\text { pregnancy, blocking } \\
\text { maternal effector T } \\
\text { cells implicated in } \\
\text { regulating the } \\
\text { remodeling of maternal } \\
\text { vasculature }\end{array}$ & {$[32,34,36,47-53]$} \\
\hline Lymphocytes & $\begin{array}{l}\text { Significantly declined } \\
\text { from follicular to luteal } \\
\text { phase }\end{array}$ & $\begin{array}{l}\text { Potentially toxic for } \\
\text { embryo and as a result } \\
\text { blocked during } \\
\text { successful gestation }\end{array}$ & {$[31,32,35,54]$} \\
\hline
\end{tabular}




\begin{tabular}{|c|c|c|c|}
\hline Cells & Changes & Functions & References \\
\hline $\begin{array}{l}\text { Neutrophil } \\
\text { granulocytes }\end{array}$ & $\begin{array}{l}\text { Show remarkable } \\
\text { elevation during late } \\
\text { luteal phase }\end{array}$ & $\begin{array}{l}\text { Involved in } \\
\text { menstruation, breaking } \\
\text { down and repairing of } \\
\text { tissue. Exert } \\
\text { pro-angiogenic and } \\
\text { tolerogenic effects in } \\
\text { the decidua of pregnant } \\
\text { women }\end{array}$ & {$[35,55-57]$} \\
\hline Macrophages & $\begin{array}{l}\text { Increase gradually from } \\
\text { follicular phase to } \\
\text { luteal phase and attain } \\
\text { peak density prior to } \\
\text { menses and during } \\
\text { pregnancy }\end{array}$ & $\begin{array}{l}\text { Participate in the } \\
\text { maintenance of corpus } \\
\text { luteum, implantation } \\
\text { of blastocyst, spiral } \\
\text { artery remodeling, } \\
\text { regulation of invasion } \\
\text { of trophoblasts, } \\
\text { embryonic protection } \\
\text { against intra-uterine } \\
\text { infection }\end{array}$ & {$[27,30,34,36,58-61]$} \\
\hline Mast cells & $\begin{array}{l}\text { Remain unaltered } \\
\text { except phenotypical } \\
\text { changes during } \\
\text { menstrual cycle and } \\
\text { become activated } \\
\text { during early and } \\
\text { mid-luteal phase }\end{array}$ & $\begin{array}{l}\text { Involved in the } \\
\text { commencement of } \\
\text { menses, enhancing the } \\
\text { remodeling of tissue } \\
\text { and spiral arteries, } \\
\text { supporting the process } \\
\text { of implantation as well } \\
\text { as angiogenesis }\end{array}$ & {$[34,62,63]$} \\
\hline
\end{tabular}

Table 3 Variation in CD4+ T cells (Th1, Th2, TH17, Tregs) and their balance in RPL women and normal women during reproductive cycle and early pregnancy

\begin{tabular}{llll}
\hline Cell type & Normal & RPL & References \\
\hline Th1 & Lower & Higher & {$[107]$} \\
Th2 & Higher & Lower & {$[107]$} \\
Th1/Th2 ratio & Lower & Higher & {$[108,109,110]$} \\
& Lower & Higher & {$[109,111,112]$}
\end{tabular}

\section{Higher}

Lower

\section{Higher}

$[114]$

Th17
Lower (proliferative and secretory phase)

Lower
Higher (proliferative and secretory phase) Higher
[115]

[106] 


\begin{tabular}{llll}
\hline Cell type & Normal & RPL & References \\
\hline Treg & Higher & Lower (proliferative & {$[115]$} \\
& phase) & Lower & {$[106]$} \\
Th17/Treg Ratio & Lower (proliferative and & $\begin{array}{l}\text { Higher (proliferative and } \\
\text { secretory phase) }\end{array}$ & secretory phase) \\
& & \\
\hline
\end{tabular}

Table 4 Overview of changes in CD4+ T cells during reproductive cycle in normal women (pregnant/nonpregnant)

\begin{tabular}{|c|c|c|}
\hline Cell-type & Changes & References \\
\hline Th1 & $\begin{array}{l}\text { No significant change during } \\
\text { reproductive cycle }\end{array}$ & {$[33]$} \\
\hline Th2 & $\begin{array}{l}\text { Diminished during mid-luteal } \\
\text { phase as compared to early } \\
\text { follicular phase }\end{array}$ & {$[33]$} \\
\hline Th1/Th2 ratio & $\begin{array}{l}\text { No significant change during } \\
\text { reproductive cycle }\end{array}$ & {$[33]$} \\
\hline \multirow[t]{5}{*}{ Th17 } & $\begin{array}{l}\text { Lower number in pregnancy } \\
\text { state compared to } \\
\text { non-pregnancy state }\end{array}$ & {$[123]$} \\
\hline & $\begin{array}{l}\text { No difference in circulating } \\
\text { Th17 cells between all } \\
\text { trimesters and non-pregnancy } \\
\text { state }\end{array}$ & {$[124]$} \\
\hline & No difference in circulating & {$[105,125]$} \\
\hline & $\begin{array}{l}\text { Th17 cells between certain } \\
\text { pregnancy period and } \\
\text { non-pregnancy period }\end{array}$ & \\
\hline & $\begin{array}{l}\text { Higher in decidua as compared } \\
\text { to blood during first trimester }\end{array}$ & {$[124]$} \\
\hline \multirow[t]{4}{*}{ Tregs } & $\begin{array}{l}\text { Density gradually increases } \\
\text { during proliferative phase in } \\
\text { peripheral blood and } \\
\text { endometrium }\end{array}$ & {$[126]$} \\
\hline & $\begin{array}{l}\text { Increase progressively in } \\
\text { peripheral blood during first } \\
\text { and second trimester while as } \\
\text { decrease during third trimester } \\
\text { as well as post-partum }\end{array}$ & {$[5,127]$} \\
\hline & $\begin{array}{l}\text { Suppressive action increased } \\
\text { during first and second } \\
\text { trimester while as weakened } \\
\text { during third trimester compared } \\
\text { to non-pregnant women }\end{array}$ & {$[128]$} \\
\hline & $\begin{array}{l}\text { Elevated in peripheral blood } \\
\text { during late follicular phase } \\
\text { compared to luteal phase }\end{array}$ & {$[52]$} \\
\hline Th17/Treg Ratio & $\begin{array}{l}\text { Lower in pregnancy as compared } \\
\text { to non-pregnancy state }\end{array}$ & {$[123]$} \\
\hline
\end{tabular}




\begin{tabular}{lll}
\hline Cell-type & Changes & References \\
\hline & Reduced during second and & {$[129]$} \\
third trimester of pregnancy & \\
compared to non-pregnancy & \\
women & \\
\hline
\end{tabular}

\begin{tabular}{|c|c|c|}
\hline Factor & Function & References \\
\hline$\overline{\text { EGR1 }}$ & $\begin{array}{l}\text { This transcription factor has } \\
\text { been predicted as key factor for } \\
\text { the decidualization of } \\
\text { endometrial stromal cells. }\end{array}$ & {$[10]$} \\
\hline Atg16L1 & $\begin{array}{l}\text { This factor is vital for } \\
\text { decidualization process, } \\
\text { implantation, and overall mice } \\
\text { fertility. This factor might also } \\
\text { serve as potent mediator of } \\
\text { successful implantation in } \\
\text { women. }\end{array}$ & [139] \\
\hline WT1 & $\begin{array}{l}\text { During the process of } \\
\text { decidualization this } \\
\text { transcription factor } \\
\text { up-regulates the expression of } \\
\text { VLDLR in human endometrial } \\
\text { cells which enhances their lipid } \\
\text { accumulation. }\end{array}$ & {$[140]$} \\
\hline IRS2 & $\begin{array}{l}\text { Progesterone regulated IRS2 } \\
\text { expression has been reported } \\
\text { critical for appropriate insulin } \\
\text { signaling for regulating the } \\
\text { expression of genes and } \\
\text { utilization of glucose that } \\
\text { significantly support the process } \\
\text { of decidualization for } \\
\text { facilitating pregnancy. }\end{array}$ & {$[137]$} \\
\hline PRL (Prolactin) & $\begin{array}{l}\text { This decidualization marker } \\
\text { when expressed prematurely in } \\
\text { luteal phase has been found } \\
\text { linked with recurrent } \\
\text { implantation failure. }\end{array}$ & {$[141]$} \\
\hline
\end{tabular}




\begin{tabular}{|c|c|c|}
\hline Factor & Function & References \\
\hline FIP200 & $\begin{array}{l}\text { This protein serves as an } \\
\text { essential agent for fertility, } \\
\text { uterine receptivity, and } \\
\text { decidualization suggesting } \\
\text { autophagy as a main cellular } \\
\text { pathway needed for uterine } \\
\text { receptivity and endometrial } \\
\text { stromal cell decidualization } \\
\text { both in humans and mice. The } \\
\text { lack of this protein causes } \\
\text { abnormal progesterone signaling } \\
\text { that leads to continual } \\
\text { proliferation of uterine } \\
\text { epithelium and impairs the } \\
\text { process of decidualization in } \\
\text { human endometrial stromal } \\
\text { cells. }\end{array}$ & {$[142]$} \\
\hline HB-EGF & $\begin{array}{l}\text { This growth factor has been } \\
\text { found greatly expressed in } \\
\text { decidua and uterine luminal } \\
\text { epithelium and essential for the } \\
\text { implantation of embryo, } \\
\text { decidualization process, and } \\
\text { gestation. }\end{array}$ & {$[143-146]$} \\
\hline MSX1 and MSX2 & $\begin{array}{l}\text { These genes act as main } \\
\text { mediators of BMP2-induced } \\
\text { decidualization in women as } \\
\text { well as mice since the reduced } \\
\text { expression of these genes by } \\
\text { little interfering RNAs highly } \\
\text { diminishes in-vitro human } \\
\text { stromal cell differentiation. }\end{array}$ & {$[135]$} \\
\hline PKM2 & $\begin{array}{l}\text { Pyruvate kinase M2 has been } \\
\text { reported as a critical potential } \\
\text { role-player during the process of } \\
\text { decidualization in early } \\
\text { gestation. }\end{array}$ & {$[136]$} \\
\hline Thrombin & $\begin{array}{l}\text { Thrombin causes extravasations } \\
\text { of leukocytes, inflammation of } \\
\text { endometrium, impairs the } \\
\text { decidualization of human } \\
\text { endometrial stromal cells as } \\
\text { well as endometrial support } \\
\text { during early stage of pregnancy. }\end{array}$ & {$[147]$} \\
\hline
\end{tabular}




\begin{tabular}{|c|c|c|}
\hline$\overline{\text { Factor }}$ & Function & References \\
\hline$\overline{\text { CXCL16 }}$ & $\begin{array}{l}\text { The CXCL16/CXCR6 axis has } \\
\text { been found as a contributor for } \\
\text { the progression of } \\
\text { decidualization of endometrial } \\
\text { stromal cells via } \\
\text { PI3K/PDK1/AKT/Cyclin D1 } \\
\text { pathway activation which } \\
\text { suggests the role of CXCL16 as } \\
\text { an initiator of molecular } \\
\text { crosstalk at maternal-fetal that } \\
\text { augments the endometrial } \\
\text { stromal cell decidualization. }\end{array}$ & {$[148]$} \\
\hline OPG & $\begin{array}{l}\text { OPG interaction with } \\
\text { syndecan-1 mediates } \\
\text { decidualization of human } \\
\text { endometrial stromal cells by } \\
\text { reducing phosphorylation of } \\
\text { Akt. OPG expression has been } \\
\text { found significantly lesser in the } \\
\text { endometrium of RPL patients } \\
\text { compared to that of with } \\
\text { normal pregnancy during the } \\
\text { first trimester. }\end{array}$ & [149] \\
\hline BMAL1 & $\begin{array}{l}\text { BMAL1 plays a useful role in } \\
\text { the process of decidualization } \\
\text { since its down-regulation in } \\
\text { RPL causes decidualization } \\
\text { impairment and abnormal } \\
\text { invasion of trophoblasts via } \\
\text { TIMP3 regulation and as a } \\
\text { result predisposes women for } \\
\text { RPL. }\end{array}$ & {$[150]$} \\
\hline CSDC2 & $\begin{array}{l}\text { This protein might serve as a } \\
\text { regulatory factor in the } \\
\text { development of decidua. }\end{array}$ & {$[151]$} \\
\hline MEIS1 & $\begin{array}{l}\text { This cofactor of HOXA10 has } \\
\text { been found as an essential agent } \\
\text { for human endometrial stromal } \\
\text { cell decidualization. }\end{array}$ & {$[152]$} \\
\hline PoFUT1 & $\begin{array}{l}\text { PoFUT1 play a crucial role in the } \\
\text { decidualization of endometrium } \\
\text { via regulating Notch } 1 \\
\text { O-fucosylation. Moreover, lower } \\
\text { poFUT1 levels have been reported } \\
\text { in the uterine endometrial tissue } \\
\text { of women that experienced } \\
\text { miscarriage compared to those } \\
\text { with early pregnancy. }\end{array}$ & [138] \\
\hline
\end{tabular}




\begin{tabular}{lll}
\hline Factor & Function & References \\
\hline Annexin A2 & The defective expression of & {$[153]$} \\
& Annexin A2 has been found & \\
& associated with impaired & \\
& endometrial stromal cell & \\
& decidualization and uterine & \\
& microenvironment both of & \\
& which are required for & \\
& promoting implantation of & \\
& embryo and placentation. & {$[8]$} \\
& These transcriptional factors & \\
& are found required for the & \\
& redundantly acting cell surface & \\
& receptors that via their & \\
concerted action regulate the & \\
& BMP signaling & \\
& receptor-complex responsible for & \\
& the decidualization of human & \\
& endometrial stromal cells. & \\
& This factor participates in & {$[119]$} \\
& angiogenesis and regulation of & \\
& decidualization and & \\
& implantation processes. & \\
\hline
\end{tabular}

Table 5 Biological factors associated with the process of decidualization

Table 6 Changes and shifts observed in Immune cell/factor in normal pregnancy vs. RPL women

\begin{tabular}{llll}
\hline Cell type/factor/Action & Normal pregnant women & RPL women & References \\
\hline dNK (CD56+) cells & Lower & Higher & {$[188]$} \\
Macrophages (CD68+) & Lower & Higher & {$[189,190]$} \\
Apoptosis & Lower & Higher & {$[189,190]$} \\
Decidual M1 macrophages & Lower & Abundant & {$[59]$} \\
Decidual M2 macrophages & Higher & Lower & {$[59]$} \\
Th17 cells & Decreased & Elevated & {$[193,194]$} \\
Treg cells & Higher & Decreased & {$[102,105,191-193,195-197]$} \\
DCs (CD83+) & Lower & Higher & {$[198,199]$} \\
DCs (CD1a+) & Higher & Lower & {$[198,199]$} \\
DC-SIGN+ cells & Increased & Reduced & {$[200]$} \\
uNK cells & Lower & Higher & {$[46,201-209]$} \\
uNK cell IL22 & Higher & Lesser & {$[210]$} \\
Pertoneal cells (CD19+ IL10+) & Increased & Decreased & {$[211]$} \\
\hline
\end{tabular}

dNK (decidual natural killer), DCs (dendritic cells), Treg (T regulatory), uNK (uterine natural killer), IL (interleukin)

\begin{tabular}{lllll}
\hline Cytokines & Sample & Cytokine level & Technique & References \\
\hline TNF $\alpha$ & Serum & Higher & Miliplex Luminex & {$[212]$}
\end{tabular}




\begin{tabular}{lllll}
\hline Cytokines & Sample & Cytokine level & Technique & References \\
\hline \multirow{4}{*}{ IFN $\gamma$} & PBL & Higher & Cytometric Bead Array & {$[213]$} \\
& Serum & Higher & ELISA & {$[214]$} \\
& Serum & Higher & ELISA & {$[215]$} \\
& Serum & Higher & Miliplex Luminex & {$[212]$} \\
& PBL & Higher & Cytometric Bead Array & {$[213]$} \\
TGF31 & Serum & Higher & ELISA & {$[214]$} \\
& Serum & Lower & ELISA & {$[115]$} \\
IL2 & Serum & Lower & ELISA & {$[215]$} \\
& Serum & Higher & ELISA & {$[215]$} \\
& PBL & Higher & Cytometric Bead Array & {$[213]$} \\
IL6 & Serum & Higher & ELISA & {$[214]$} \\
& Serum & Lower & Miliplex Luminex & {$[212]$} \\
IL8 & PBL & Higher & qRT-PCR & {$[194]$} \\
IL10 & Serum & Higher & Miliplex Luminex & {$[212]$} \\
& Serum & Lower & ELISA & {$[215]$} \\
& PBL & Lower & Cytometric Bead Array & {$[213]$} \\
LIF & Serum & Lower & ELISA & {$[115]$} \\
IL17 & Serum & Higher & ELISA & {$[214]$} \\
& PBL & Higher & qRT-PCR & {$[194]$} \\
IL23 & Serum & Higher & ELISA & {$[115]$} \\
\hline
\end{tabular}

Table 7 Variation in cytokines levels in peripheral blood of RPL patients in comparison to normal women TNF $\alpha$ (Tumor necrosis factor- $\alpha$ ), IFN $\gamma$ (Interferon- $\gamma$ ), TGF $\beta$ (Transforming growth factor- $\beta 1$ ), IL (Interleukin), LIF (Leukemia inhibitory factor), ELISA (Enzyme-Linked Immunosorbent Assay), qRT-PCR (Quantative real time - polymerase chain reaction), PBL (Peripheral blood lymphocytes)

Table 8 Variation in endometrial and decidual cytokine levels in RPL women vs. normal women

\begin{tabular}{lllll}
\hline Cytokine & Sample & Cytokine level & Techniques & References \\
\hline TNF $\alpha$ & Decidua & Elevated & RT-PCR and ELISA & {$[193]$} \\
IFN $\gamma$ & Decidua & Elevated & ELISA & {$[215]$} \\
& Endometrium & Elevated & ELISA & {$[216]$} \\
TGFß1 & Decidua & Declined & RT-PCR and ELISA / ELISA & {$[193,215]$} \\
IL1 $\alpha$ & Endometrium & Declined & RT-PCR & {$[217]$} \\
IL1 $\beta$ & Endometrium & Declined & RNase protection assay & {$[218]$} \\
IL2 & Decidua & Elevated & qRT-PCR and ELISA / ELISA & {$[114,215]$} \\
IL4 & Decidua & Declined & qRT-PCR and ELISA & {$[114]$} \\
IL6 & Decidua & Elevated & RT-PCR & {$[193]$} \\
& Endometrium & Declined & RT-PCR & {$[217]$} \\
IL8 & Decidua & Elevated & Microarray & {$[219]$} \\
IL10 & Decidua & Declined & qRT-PCR and ELISA / ELISA & {$[114,215]$} \\
IL12 & Endometrium & Elevated & ELISA & {$[216]$} \\
IL17 & Decidua & Unaltered & qRT-PCR, WB, and IHC & {$[210]$} \\
IL23 & Decidua & Unaltered/ Elevated & qRT-PCR, WB, and IHC / qRT-PCR, and WB & {$[102,210]$} \\
LIF & Endometrium & Declined & ELISA & {$[216]$} \\
\hline
\end{tabular}

TNF $\alpha$ (Tumor necrosis factor- $\alpha$ ), IFN $\gamma$ (Interferon- $\gamma$ ), TGF $\beta$ (Transforming growth factor- $\beta 1$ ), IL (In- 
terleukin), LIF (Leukemia inhibitory factor), ELISA (Enzyme-Linked Immunosorbent Assay), qRT-PCR (Quantative real time-polymerase chain reaction), IHC (Immunohistochemistry), WB (Western blotting)

Table 9 Endometrial and decidual immune cells with their cytokines

\begin{tabular}{|c|c|c|c|c|c|c|}
\hline Cell-Type & Cell-Type & $\begin{array}{l}\text { Percentage } \\
\text { in } \\
\text { Endometrium }\end{array}$ & $\begin{array}{l}\text { Cytokines } \\
\text { Secreted }\end{array}$ & $\begin{array}{l}\text { Cytokine } \\
\text { type } \\
\text { (pro-/anti- } \\
\text { inflammatory) }\end{array}$ & $\begin{array}{l}\text { Immunity } \\
\text { type }\end{array}$ & References \\
\hline Uterine & Uterine & \multirow{6}{*}{$70 \%$} & \multirow{6}{*}{$\begin{array}{l}\text { IFN } \gamma, \\
\text { TNF } \alpha \text {, IL10, } \\
\text { TGF } \beta \text {, IL1 } \beta \text {, } \\
\text { CSF-1, } \\
\text { GM-CSF }\end{array}$} & \multirow[t]{6}{*}{ Th1 \& Th2 } & \multirow[t]{6}{*}{ Innate } & \multirow{6}{*}{$\begin{array}{l}{[9,29,30} \\
34,43-46]\end{array}$} \\
\hline Natural & Natural & & & & & \\
\hline killer (uNK) & killer (uNK) & & & & & \\
\hline cells (CD3-' & cells $\left(\mathrm{CD}^{-}\right.$ & & & & & \\
\hline CD56 bright & CD56 $6^{\text {bright }}$ & & & & & \\
\hline CD16-) & CD16-) & & & & & \\
\hline $\begin{array}{l}\text { Macrophages } \\
(\mathrm{CD} 68+)\end{array}$ & $\begin{array}{l}\text { Macrophages } \\
(\mathrm{CD} 68+)\end{array}$ & $20-25 \%$ & $\begin{array}{l}\text { IL10, } \\
\text { TGF } \beta, P G E 2\end{array}$ & Th2 & Innate & $\begin{array}{l}{[27,30,34,} \\
36,58-61]\end{array}$ \\
\hline $\begin{array}{l}\text { T Lympho- } \\
\text { cytes } \\
\text { (CD45+ } \\
\text { CD3+) }\end{array}$ & $\begin{array}{l}\text { T Lympho- } \\
\text { cytes } \\
(\mathrm{CD} 45+ \\
\text { CD3+ ) }\end{array}$ & $1-28 \%$ & Varies & - & Adaptive & {$[29-32]$} \\
\hline \multirow[t]{4}{*}{$\mathrm{CD} 4+\mathrm{T}$ cells } & Th1 & $3.8-21.4 \%$ & $\mathrm{IFN}_{\gamma}, \mathrm{TNF} \alpha$ & Th1 & Adaptive & $\begin{array}{l}{[31,36,47][32,} \\
34,36,47-53]\end{array}$ \\
\hline & Th2 & & IL4 & Th2 & & \\
\hline & Th17 & & IL8 & Th17 & & \\
\hline & Treg & & IL10, TGF $\beta$ & Th2 & & \\
\hline $\begin{array}{l}\text { Uterine } \\
\text { dendritic } \\
\text { cells } \\
\text { (Immature } \\
\text { DCs } \\
(\mathrm{CD} 1 \alpha+) ; \\
\text { mature DCs } \\
(\mathrm{CD} 83+))\end{array}$ & $\begin{array}{l}\text { Uterine } \\
\text { dendritic } \\
\text { cells } \\
\text { (Immature } \\
\text { DCs } \\
(\mathrm{CD} 1 \alpha+) ; \\
\text { mature DCs } \\
(\mathrm{CD} 83+))\end{array}$ & $1-2 \%$ & $\begin{array}{l}\text { TGF- } \beta \text {, } \\
\text { IL-10 }\end{array}$ & Th2 & Innate & $\begin{array}{l}{[30,36,} \\
37-42]\end{array}$ \\
\hline $\begin{array}{l}\text { B } \\
\text { lymphocytes } \\
\text { (CD45+ } \\
\text { CD19+) }\end{array}$ & $\begin{array}{l}\text { B } \\
\text { lymphocytes } \\
\text { (CD45+ } \\
\text { CD19+) }\end{array}$ & $0.2-4.5 \%$ & IL-10 & Th2 & Adaptive & {$[31,34,35]$} \\
\hline
\end{tabular}

Table 10 Biological action. Illustrating the biological roles of different factors associated with pregnancy outcome

\begin{tabular}{ll}
\hline Factors & Biological action \\
\hline IL33 & IL33 regulates the factors essential for decidual receptivity duri \\
IL11 & It is a vital cytokine associate with decidualization, implantatio \\
dNK cells & They primarily support the trophoblasts incursion and vascular \\
IFN $\gamma$ & It causes the activation of macrophages present in decidua whic \\
IL4 and IL10 & They could impede the functions both of Th1 type of cells as w \\
IFN $\gamma$, IL4, IL6, TNF $\alpha$, TGF $\beta$, M-CSF and LIF receptors & These receptors existing on the surface of trophoblastic cells col \\
M-CSF (macrophage colony stimulating factor) & This factor is responsible for inciting trophoblast proliferation il
\end{tabular}


Factors

LIF(Leukemia-inhibitory factor)

IL8

IL10

IL15

$\mathrm{TNF} \alpha$ and IFN $\gamma$

$\mathrm{TNF} \alpha$

Foxp3 Mrna

Treg cells

Micro-RNA (miR-155)

Endometrial EGR1
Biological action

Essential for endometrial implantation and fetal development. One of the pro-angiogenic cytokines responsible for stimulating Expressed at materno-embryonic interface and inhibits the form This interleukin is considered as a key factor for stimulating inThey hamper the development of embryo and the production of During pregnancy it along with hormones brings about thrombe $\mathrm{TNF} \alpha$ has been found linked with the process of inflammation a Diminished expression in endometrial tissue is linked with prim The trophoblasts of RPL patients show decreased expression of They down regulate the inflammatory responses and protects th Decreased percentage of decidual Treg cells has been associated The materno-embryonic tolerance mediated by Treg cells has be The reduced level of immune-regulatory microRNA miR-155 ha The decreased levels of EGR1 have been observed in women the 